\title{
The Cross-Country Incidence of the Global Crisis
}

Philip R. Lane and Gian Maria Milesi-Ferretti 


\title{
IMF Working Paper
}

\author{
Research Department
}

The Cross-Country Incidence of the Global Crisis ${ }^{1}$

\section{Prepared by Philip R. Lane and Gian Maria Milesi-Ferretti}

July 2010

\begin{abstract}
This Working Paper should not be reported as representing the views of the IMF. The views expressed in this Working Paper are those of the author(s) and do not necessarily represent those of the IMF or IMF policy. Working Papers describe research in progress by the author(s) and are published to elicit comments and to further debate.

We examine whether the cross-country incidence and severity of the 2008-2009 global recession is systematically related to pre-crisis macroeconomic and financial factors. We find that the pre-crisis level of development, increases in the ratio of private credit to GDP, current account deficits, and openness to trade are helpful in understanding the intensity of the crisis. International risk sharing did little to shield domestic demand from the countryspecific component of output declines, while those countries with large pre-crisis current account deficits saw domestic demand fall by much more than domestic output during the crisis.
\end{abstract}

JEL ClassificatioNumbers: F31, F32

Keywords: financial crisis, current account, private credit, international financial integration

Author's E-Mail Address: gmilesiferretti@imf.org; plane@tcd.ie

\footnotetext{
${ }^{1}$ Revised version of the paper prepared for the IMF/BOP/PSE Conference "Economic Linkages, Spillovers and the Financial Crisis," Paris, January 28-29 2010. We thank Giancarlo Corsetti, Pierre-Olivier Gourinchas, Ayhan Kose, Andy Rose, Nelson Souza-Sobrinho, Mark Spiegel, two anonymous referees, and participants to the Paris conference and to the XII Workshop in International Economics and Finance in Rio de Janeiro for comments and suggestions. We are grateful to John Kowalski, Barbara Pels, and Donal Mullins for helpful research assistance.
} 


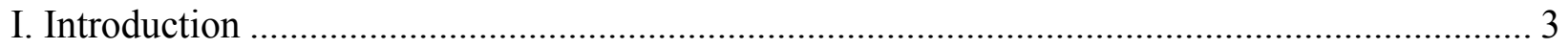

II. The crisis: Key Channels of Transmission............................................................................. 5

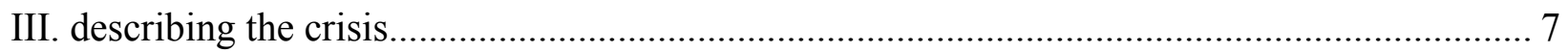

A. Change in growth rates ............................................................................................ 7

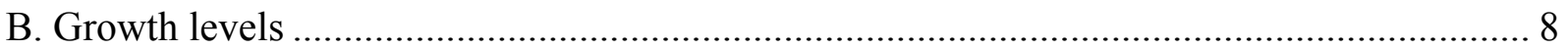

C. Pre-crisis variables and crisis outcome ................................................................ 9

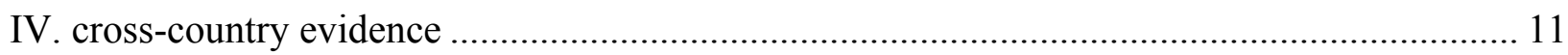

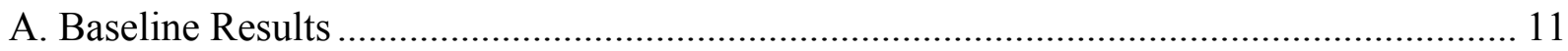

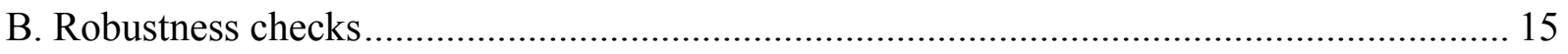

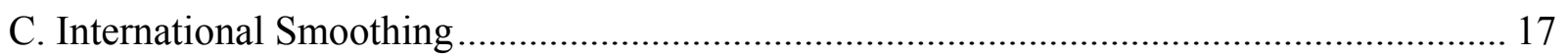

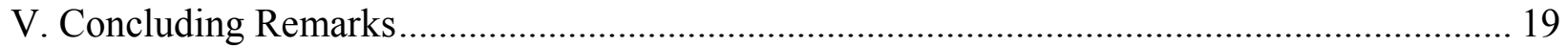

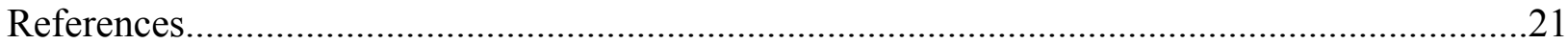

Appendix

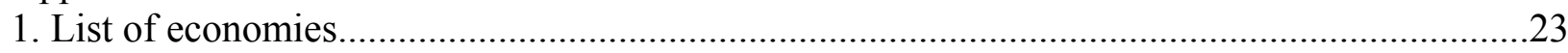

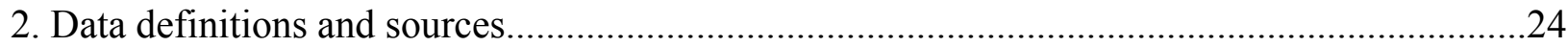

Tables

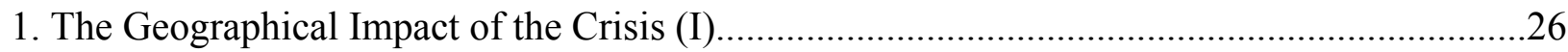

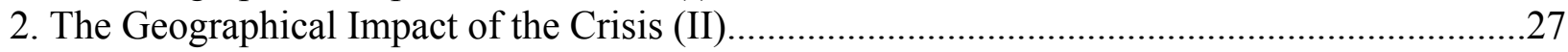

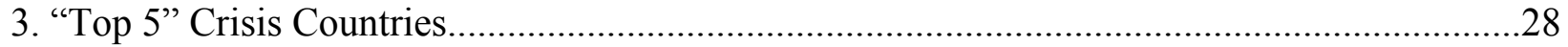

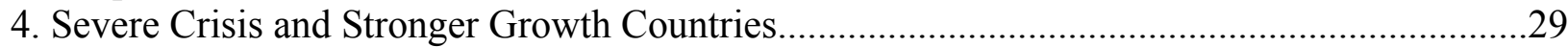

5. Severe Crisis and Stronger Growth Countries, excluding low-income countries....................30

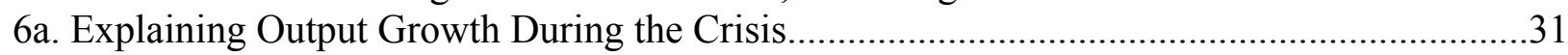

6b. Growth Residuals and Change in Output Growth in Trading Partners................................32

7a. Explaining Demand Growth During the Crisis................................................................33

7b. Demand Growth Residuals and Change in Output Growth in Trading Partners....................34

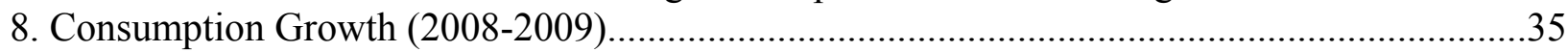

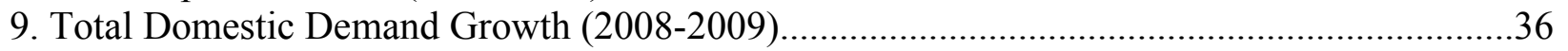

Figures

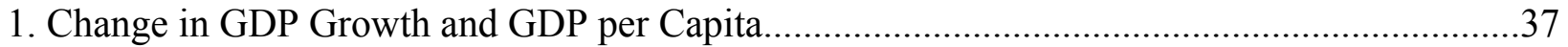

2. Change in Demand Growth and Current Account Balance....................................................38

3. Decline in Demand Growth and Growth in Private Credit...................................................39 


\section{INTRODUCTION}

Our general goal in this paper is to understand the cross-country variation in the macroeconomic impact of the global financial crisis of 2008 and 2009. In particular, we aim to identify initial conditions that may help to explain the differential response of output and demand in different countries and regions to the global shock, with a special emphasis on financial factors, both domestic and cross-border. The standard narrative of the transmission of the global financial crisis emphasizes the role played by international financial linkages. The original shock in the US financial system led to disruption in the financial systems of several advanced European countries and others around the world. In turn, the disruption in the financial system gradually transmitted to the real economy, with the financial crisis inducing a contraction in economic activity and remarkable declines in international trade and international capital flows in late 2008 and early 2009.

While the scale of the crisis was clearly missed by most commentators, its transmission across countries seems easier to understand with the benefit of hindsight. The most affected countriesparticularly those that had to rely on official external support - had severe asset price bubbles, large financial sector exposures, and/or heavy reliance on external capital flows because of large current account deficits. Yet the empirical work by Rose and Spiegel (2009a, 2009b) indicates that it is very difficult to understand the cross-country variation in the depth of the crisis if we focus on variables measuring cross-border trade and financial linkages. More generally, these authors fail to find any pre-crisis variable that is a robust correlate of the decline in growth since the onset of the crisis, in contrast with the "impressionistic" view sketched above.

In our empirical work we revisit the question of whether the cross-country incidence and severity of the crisis is systematically related to pre-crisis macroeconomic and financial factors, and argue that the evidence supports at least in part the "impressionistic view" that pre-crisis variables are helpful in understanding the intensity of the crisis. We focus on the impact of the crisis on the level of economic activity, rather than on the cross-country variation in the scale of the decline in asset prices or financial flows. In addition to examining differences in output growth across countries, we also examine the dynamics of consumption and total domestic demand. This is important, since much of the theoretical literature on international financial integration focuses on the possibilities provided by international capital markets for de-linking domestic expenditure and domestic production. Through ex-ante risk sharing, domestic wealth is diversified away from an exclusive reliance on domestic assets and part of the risk of domestic shocks is transferred to foreign investors. Through international borrowing and lending, domestic expenditure can be smoothed in the event of a domestic production shock, even if ex-ante risk sharing is low or nonexistent.

However, in the other direction, financial integration also means that domestic macroeconomic behavior can be affected even if there are no shocks to domestic production. First, the wealth of domestic agents is influenced by the impact of foreign asset price shocks both directly through the holding of foreign assets and indirectly through the international transmission of asset price shocks across borders (Krugman 2008, Devereux and Yetman 2010). Second, an international shift in the level of risk aversion will affect the cross-border lending and borrowing possibilities for domestic agents. 
We may expect the relative importance of these factors to differ across countries in line with differences in the degree of international financial integration and the vulnerability of different countries to a shift in international credit conditions. In our empirical work, we seek to establish whether there are indeed links between such measures and the severity of the macroeconomic crisis.

In relation to output dynamics, the global credit crisis may be expected to most adversely affect production in those countries that were most reliant on credit expansion during the pre-crisis period. In particular, it is plausible that those economies in which domestic private credit was growing strongly and which were experiencing net capital inflows during the pre-crisis period may have faced the greatest adjustment difficulties once the credit crisis hit. In particular, these economies would face a greater adjustment challenge in dealing with the contraction in the supply of credit and the increase in the cost of credit.

In addition to such financial factors, the dramatic decline in world trade during late 2008 and early 2009 and the especially adverse impact of global uncertainty on the durables sector mean that part of the differential macroeconomic response to the crisis can likely be attributed to differences in national exposures to world trade and the relative size of the manufacturing sector. Accordingly, we explore the extent to which these real-side variables are correlated with the intensity of the crisis.

Our focus is on the cumulative shift in output, consumption and total domestic demand over 2008-2009, and how international financial integration has influenced macroeconomic behavior over this period - we do not attempt to trace out the higher-frequency transmission of the global crisis. Hence our study is complementary to the many recent contributions that have examined in detail the higher-frequency dynamics by which the international financial system propagated the initial shock in the US sub-prime market throughout the global system.

The literature on the macroeconomic impact of the current crisis is growing rapidly, although there is substantial variation across the studies in terms of methods and sample periods. Rose and Spiegel (2009a, 2009b) seek to explain output growth in 2008 jointly with several asset market indicators, while Berglof et al (2009) focus on projected output growth for 2009 for a large group of countries and output growth over the last quarter of 2008 and the first quarter of 2009 for a smaller group of Central and Eastern European countries. Blanchard, Faruqee, and Das (2010) relate the unexpected component of output declines at the height of the crisis (last quarter of 2008 and first quarter of 2009) to variables measuring the intensity of external trade and financial shocks for a group of 29 emerging markets. International Monetary Fund, 2010 focuses on the economic performance of emerging markets during the crisis more generally, including the role of policy responses. We instead consider the behavior of macroeconomic variables over a two year interval (2008 and 2009, where the 2009 data are based on estimates from April 2010) for a global sample of countries, and include private consumption and total domestic demand in addition to GDP. We consider that a time period encompassing two years is likely to better capture the incidence of the crisis, particularly since we consider the largest possible sample of countries and the transmission of the crisis to many economies, particularly emerging and developing ones, took place gradually. 
Giannone et al (2010) also study the cross-sectional variation in output growth during 20082009. Their main aim is to estimate how institutional factors (in particular, the regulatory regime governing credit markets) affected the severity of the crisis, whereas our study includes a larger set of regressors and our focus is on the association between a set of pre-crisis macroeconomic and financial indicators and performance during the crisis. In relation to the connections between trade and financial openness and crisis performance, Imbs (2010) provides a complementary empirical analysis that focuses on patterns of co-movement across country pairs, whereas our aim is to explain the variation across countries. Finally, Berkmen et. al. (2009) focus on changes in growth projections for 2009 between the period before and after the collapse of Lehman Brothers. They find that growth projections were revised downwards more severely in countries with more leveraged domestic financial systems and more rapid credit growth.

This paper is also related to the vast literature on exchange rate and banking crises in emerging markets (see, for example, Kaminsky and Reinhart, 1999). While a substantial number of those contributions aim at identifying variables that help explain the occurrence of a crisis, there are some papers that also seek to explain the intensity of output declines following a crisis (see, for example, Milesi-Ferretti and Razin, 2000; Gupta, Mishra, and Sahay, 2007). In line with this literature, we find that the output decline during the current crisis was larger in countries experiencing large pre-crisis net capital inflows and fast credit growth. However, trade openness in the current crisis did not help cushion output declines, in light of the global nature of the downturn and the heavy toll on advanced economies.

Our paper is organized as follows. In Section II we briefly discuss our conceptual framework. In section III we provide the key stylized facts associated with the 2008-2009 crisis in terms of the cross-country variation in the scale of the growth slowdown in output and the various components of domestic expenditure. In Section IV we investigate the covariates of the growth slowdown in a cross-country regression framework, with a particular emphasis on the role played by indicators of international financial integration. Section V concludes.

\section{The CRISIS: Key Channels OF TRANSMISSION}

There is already an extensive literature detailing the development of the financial crisis (see, for example, Brunnermeier, 2009; CES Ifo, 2009). In this section we briefly sketch different crisis transmission channels and discuss which pre-crisis factors could help capture the intensity of these channels.

The first channel of transmission was exposure to U.S. assets backed by sub-prime mortgages. A cross-country measure of sub-prime exposure could be obtained from the U.S. Treasury survey of U.S. portfolio liabilities as of end-June 2007 (just before the inception of the crisis). This survey reports the amount of U.S.-issued private mortgage-backed securities held by foreign residents on a country-by-country basis. As discussed in Milesi-Ferretti (2009), these data show relatively high exposures in several advanced European countries with large banking systems (such, as for example, France, Germany, Switzerland, and the United Kingdom) whose financial institutions were severely affected by the sub-prime shock. However, it is difficult to make use of these data for a more systematic cross-country analysis, primarily because the residence of the financial entities holding these securities is not necessarily a good proxy for their ultimate 
exposure: for example, the largest holder of these securities was by far the Cayman Islands. ${ }^{2}$ An alternative measure of exposure would be the size of cross-border bank positions or the reliance on external bank financing, in light of the scope of the crisis affecting such a wide array of large financial institutions.

A second channel of international financial transmission was a global increase in risk aversion, related to two factors:

a. The realization of the extent of systematic under-pricing of risk in previous years (including in lending to "risky countries"). It is plausible that the dramatic change in risk perceptions and tolerance would hit hardest those countries with large current account deficits, large net external liabilities, or large gross liabilities with currency and maturity mismatches.

b. The prevalence of real estate and asset price bubbles. This channel would suggest that variables such as the growth in domestic credit, as well as measures of growth in asset prices, may be correlated with subsequent declines in output growth and demand.

A third, related channel of transmission operated through the reliance on those financial systems that got hit hardest by the crisis. The most obvious channel here would be through foreign banks pulling back funds and curtailing credit. Given that the banking systems of advanced economies were those disproportionately affected by the crisis, net liabilities to BIS-reporting countries could proxy for the intensity of this channel. More generally, borrowing countries suffered also through the dependence on external bond financing, because financial intermediaries, such as hedge funds, which were important investors in portfolio instruments were forced to reduce leverage because of withdrawals. Measures of gross and net external debt liabilities would be possible measures capturing the intensity of this channel (the latter measure would take into account the possibility of using foreign exchange reserves to offset loss of access to external financing).

Finally, a key channel of transmission was through the global collapse in trade, and particularly in demand for durable and investment goods, driven by uncertainty, credit woes etc. Because manufactured goods are more "cyclical", their producers are likely to suffer more. And of course openness to trade increases the exposure to external demand shocks. A related channel is the collapse in demand for commodities (oil prices plummeted) that hit the revenues of commodity exporters. However, we are looking at growth over 2008-09, a period during which, on average, oil prices and commodity prices in general were very strong. In any case, in our empirical analysis we investigate whether results are affected by the inclusion or exclusion of oil-exporting countries.

\footnotetext{
${ }^{2}$ Empirical work by Acharya et al. (2009) documents how banks more exposed to these assets experienced larger losses. However, Kamin and Pounder DeMarco (2010) find little evidence that countries that held large amounts of U.S. mortgage-backed securities and were highly dependent on dollar funding experienced greater financial distress during the crisis.
} 


\section{DESCRIBING THE CRISIS}

We focus on crisis measures defined in terms of declines in economic activity (rather than as declines in asset prices). Specifically, we construct several measures of crisis intensity, based on the growth rates in output, domestic demand, and its components (private and public consumption, investment, exports, and imports). For output and demand growth, these crisis measures take two forms:

- $\quad$ the growth rate during 2008-2009;

- $\quad$ The change in the growth rate between 2008-2009 and the boom period 2005-2007.

We have also considered alternative definitions of crisis intensity: for example, the difference between growth in 2008-2009 and trend growth (defined as the average growth rate for the period 1990-2007). The stylized facts we present in this Section are very similar to those one obtains with this alternative definition of crisis intensity. The correlation between the two "difference in growth" measures is 0.75 , and rises to 0.88 when oil exporters are excluded from the sample.

The source of data for growth rates is the April 2010 World Economic Outlook. We use these data, together with data on a set of correlates dated prior to the onset of the crisis, to identify a number of stylized facts. We focus first on the geographical pattern of the crisis, and then turn to a characterization of pre-crisis variables in countries differentially affected by the global downturn. A simple statistic can convey the intensity of the crisis: for about 50 countries, the growth rate during 2008-2009 was at least 4 percentage points lower than during the period 1990-2007.

\section{A. Change in growth rates}

In order to characterize the geographical dimension of the crisis, we construct a global ranking for each of several macroeconomic crisis measures (changes in output growth, demand growth, private and public consumption growth, investment growth, export growth, and import growth) and then average the rankings. Different crisis measures are correlated, but not dramatically so. In particular:

- $\quad$ The correlation of changes in private consumption growth with changes in output growth is modest. However, the correlation rises significantly if we exclude oil exporters. One explanation is that in these countries the decline in oil output growth was significant given the world slowdown, but consumption levels remained high, also helped by the strong terms of trade.

- $\quad$ The correlation of export growth with GDP growth is relatively strong, but the correlation of export growth with domestic demand components is weak. Again, this is not very surprising, to the extent that export growth is primarily driven by the strength of demand in trading partners.

As documented in Table 1A, the crisis has a strong regional component: emerging Europe plus countries of the Commonwealth of Independent States (CIS) altogether account for 
12 of the "top 20" crisis countries. ${ }^{3}$ The second highest total ( 3 countries) is for advanced economies (3 countries: Ireland, Iceland, and Spain) and the third is for Latin American countries (Mexico and Venezuela). The top panel of Table 2 provides more systematic evidence of the significant regional differences in the incidence of the crisis, with emerging Europe, CIS, Caribbean countries, and industrial economies experiencing the sharpest declines in growth, while these declines were more modest in Africa and the Middle East.

The top panel of Table 3 provides a list of the most severely affected countries, highlighting how the Baltic countries, Armenia, the Ukraine, and Iceland were affected particularly severely. Some individual country patterns prima facie suggest the importance of cross-border linkages. For example, Mexico is among the "top 20" countries in terms of output and demand declines, with the close linkages to the U.S. economy likely playing a crucial role (in addition to the idiosyncratic contribution of the swine flu epidemic).

\section{B. Growth levels}

Measures of the crisis based on changes in growth rates can single out countries that experienced significant output declines, but where growth remained positive, and miss others that were growing more slowly in the period 2005-2007 but then experienced a severe recession. A major difference between a rank analysis of changes in growth rates and growth levels during the crisis period is the heavy presence of industrial countries among the countries with the lowest growth levels during 2008-09. Indeed, industrial countries and countries in emerging Europe account for 17 of the top 20 and 23 of the top 30 crisis countries when ranked by the 2008-2009 growth rate (Table 1B). There are two reasons for this: one is the "industrial country nature" of the crisis, and the second is the fact that average pre-crisis growth rates in industrial countries, while high, were lower in comparison to growth rates for emerging markets, and hence overall growth declines were not necessarily as large (Table 2).

Among individual countries, those that experienced the most severe crisis are the Baltics, Ukraine, and Iceland (Table 3, bottom panel), followed by advanced economies such as Ireland, Italy, and Japan and emerging markets such as Hungary and Mexico. Again, this evidence prima facie suggests a variety of mechanisms at play: Italy and Japan were not severely affected by sub-prime spillovers, but Italy was facing growth woes before the crisis, and Italian banks have large exposures to countries in emerging Europe. On the other hand, Japan was also growing more slowly and, as a large exporter of manufactured goods, suffered from the collapse in investment across the globe. Hungary, a country with net external liabilities of around 100 percent of GDP in 2007, suffered a severe external crisis, and Ireland's output collapsed following the bursting of a housing bubble and related banking woes.

Finally, it is worth pointing out that some commodity exporters (which experienced big declines in output growth, and hence rank high among crisis countries using the change in growth

\footnotetext{
${ }^{3}$ Berglof et al (2009) focus on the factors explaining the incidence of the crisis on the region.
} 
measure), did not experience the most severe recessions: among those are Latin American countries such as Venezuela as well as CIS countries such as Kazakhstan. ${ }^{4}$

\section{Pre-crisis variables and crisis outcome}

Having established some initial stylized facts on the geographical incidence of the crisis, we turn now to a characterization of real and financial indicators in countries that were most severely affected by the crisis. We focus on three crisis measures related to output, private consumption, and total domestic demand. We choose thresholds to identify countries most severely affected by the crisis that single out some 40 countries (around a quarter of our sample) for each growth decline measure. Specifically, our crisis definition requires negative growth during 2008-2009, as well as a certain threshold decline in the growth rate relative to 2005-2007: at least 4 percentage points for output, 5 percentage points for domestic demand, and 3 percentage points for private consumption. ${ }^{5}$ We then select thresholds that single out the same number of countries in the sample whose growth performance has instead been strongest and compare the mean and median values of several macroeconomic and financial variables across the two samples. We should note that, on the basis of the chosen threshold, the United States does not stand out as one of the countries most severely affected by the global crisis - the U.S. suffered a severe crisis according to the decline in private consumption definition, but not according to the decline in output or demand growth definition. ${ }^{6}$ Note also that the results are virtually identical if we use the differences in output and demand growth between 2008-2009 and longer-term growth averages (1990-2007).

Our core group of macroeconomic and financial variables includes GDP per capita, the current account balance in the run-up to the crisis (average over the period 2005-2007), the ratio of private credit to GDP in 2007 and the change in that ratio in the run-up to the crisis (2004-2007), and a series of variables related to gross and net external exposure of countries as of end-2007, such as the level of financial openness, the net position vis-à-vis BIS-reporting banks, the net foreign asset position, the level of short-term external debt, and the stock of foreign exchange reserves.

The results for the change in output and demand growth are presented in Table 4, which reports the difference in median values and mean values across the "severe crisis" and "less severe crisis" samples, as well as the t statistic for the test of whether the difference in mean values is

\footnotetext{
${ }^{4}$ These findings clearly depend on the chosen definition of the crisis period (2008-2009). In these countries, growth until mid-2008 was sustained by record-high oil and commodity prices.

${ }^{5}$ The decline in private consumption is generally more modest than the decline in output and demand, while the decline in investment is larger.

${ }^{6}$ This may help explain the finding of Rose and Spiegel (2009b) who fail to uncover any statistically significant link between bilateral trade and financial linkages with the United States and the intensity of the crisis. We also experimented with a variety of controls for bilateral financial and trade linkages vis-à-vis the United States in our statistical analysis, but find little evidence of a statistically significant relation between these linkages and the intensity of the crisis.
} 
statistically different from zero. One striking result is the very large difference in GDP per capita between the countries more severely affected by the crisis and those least affected. Indeed, there are no low-income countries (defined as countries with GDP per capita below $\$ 1000$ in 2007) that experienced a severe GDP crisis, and only two that experienced a demand crisis. Among other notable differences between the two samples, countries experiencing a more severe crisis tend to have a larger share of manufacturing in GDP, a higher ratio of private credit to GDP, and a larger increase in that ratio for the period 2004-2007. We also find some evidence that countries with higher reserves experienced smaller declines in demand and, for emerging and developing countries, we find that countries with higher short-term debt as a ratio of reserves experienced sharper output and demand declines. ${ }^{7}$

It is more difficult to identify clear stylized facts from other international financial variables, because of the importance of financial center outliers that have a very strong influence on mean values. For example, the mean difference in the financial openness ratio between the two samples is over 800 percent of GDP, skewed by the presence of Luxembourg among the crisis countries. ${ }^{8}$ We therefore performed a second set of mean and median comparisons between the countries most and least affected by the crisis on a reduced sample which excludes both lowincome countries (those with GDP per capita below 1000 dollars in 2007) and financial centers, defined as countries with a financial openness ratio in 2007 that exceeds 800 percent, plus a selected group of small countries that are international banking centers or with significant offshore activity. ${ }^{9}$

The results are presented in Table 5; again for output and demand crises (the results for private consumption crises are virtually identical to those for demand crises). Differences in the share of manufacturing, private credit level and growth rate, and GDP per capita still persist, but in addition a number of variables related to net external vulnerabilities (the current account balance in the pre-crisis period, the net external position, the net position vis-à-vis BIS banks, and the net debt position) show significant differences between the two samples, with the countries more severely affected characterized by higher current account deficits and net external liabilities. These differences are also economically significant: for demand crisis countries, the current account balance was worse on average by close to 8 percentage points of GDP, with a median difference of 7 percentage points of GDP. And for output crisis countries, the change in the ratio of private credit to GDP exceeded the one for the least affected countries by 10-12 percentage points. And again, for the set of developing countries and emerging markets, we find that those

\footnotetext{
${ }^{7}$ The variable short-term debt at remaining maturity over reserves is not available for advanced economies. While it is possible to construct a short-term debt series (albeit not at remaining maturity) for these economies, its median level as a ratio of reserves (2600\%) is a large multiple of the one for emerging and developing countries (24\%), hindering a proper comparison of this variable between crisis and noncrisis samples.

${ }^{8}$ At end-2007, the sum of financial assets and liabilities in Luxembourg was over 200 times GDP.

${ }^{9}$ The first group includes Bahrain, Belgium, Cyprus, Iceland, Ireland, Liberia, Luxembourg, Malta, the Netherlands, Hong Kong S.A.R., Singapore, Switzerland, and the United Kingdom. The second includes Belize, Mauritius, Panama, Samoa, Seychelles, St. Vincent and the Grenadines, and Vanuatu.
} 
with higher pre-crisis short-term debt as a ratio of reserves experienced sharper output and demand losses.

Given the financial nature of the crisis, it is also interesting to ask how financial centers fared relative to other countries. Some 35-40 percent of them were among the "severe crisis" countries (according to both the output and demand definition), a higher ratio of the rest of the countries in the sample. A more formal comparison shows that financial centers had significantly lower output and demand growth during the crisis relative to all other countries; the mean decline in output and demand growth was also larger, but not significant at the 95 percent confidence level.

In Figure 1-3 we provide some visual evidence of the strong bilateral correlations between the decline in output and demand growth and variables such as GDP per capita, the growth rate in private credit, and the 2007 current account balance.

In sum, these results lend support to the notion that the recent financial crisis affected advanced economies particularly severely, and that countries with a high share of manufacturing in GDP, large increases in private credit relative to GDP, high current account deficits, and net external liabilities - particularly in the form of debt-were among those experiencing higher output and demand declines. Of course some of these variables are correlated: for example, richer countries are also more financial developed and have higher ratios of credit to GDP. We therefore turn now to multivariate econometric analysis to investigate which pre-crisis variables show statistically significant conditional correlations with output and demand declines.

\section{CROSS-COUNTRY EVIDENCE}

\section{A. Baseline Results}

We investigate the covariates of the output slowdown by estimating specifications with the format

$$
\hat{Y}_{i, 0809}=\alpha+\beta_{1} * \hat{Y}_{i, 0507}+\beta_{2} * \hat{Y}_{i, \text { trend }}+\beta_{3} * R_{i}+\beta_{4} * F_{i}+\beta_{5} * Z_{i}+\varepsilon_{i}
$$

where $\hat{Y}_{i, 0809}$ is average GDP growth in 2008-09, $\hat{Y}_{i, 0507}$ is average GDP growth over 2005-07, $\widehat{Y}_{i, \text { trend }}$ is the average growth rate over 1990-2007, the vector $R_{i}$ consists of real-side variables, $F_{i}$ financial-side variables and $Z_{i}$ general control variables. Note that we do not include any regressors that are based on 2008-2009 realizations; rather, our goal is to identify 'initial conditions' that help to explain the slowdown during this period.

This is a very flexible specification, which is isomorphic to specifications seeking to explain the change in the growth rate relative to trend or relative to the period 2005-2007 (for example, in the first case the coefficient on $\hat{Y}_{i, \text { trend }}$ becomes $\beta_{2}-1$ ). Similarly, it is possible to express both the LHS and RHS variables as deviations from, say, growth during 2005-07. The real-side variables are the level of trade openness in 2007, the manufacturing share in GDP in 2007, and a dummy variable (OIL) that takes the value 1 for oil producers and 0 otherwise. The first two variables are 
included since the contraction in economic activity in large advanced economies was transmitted across borders via a significant contraction in world trade and an especially large decline in the manufacturing sector. The oil dummy is included to take into account the impact of the shift in oil prices on economic activity levels in oil-exporting nations. (We will also report results for a subsample that excludes the oil-exporting group).

We consider both domestic and international financial variables. In relation to the former, we include the increase in the ratio of private credit to GDP over the period 2004-2007. This is included in view of the potential structural vulnerabilities generated by credit growth much above the rate of GDP growth during the pre-crisis period. In relation to the international financial variables, we consider both net and gross measures. We include the 2007 value for the current account balance, since the increase in risk aversion during the crisis plausibly had a differential impact on deficit countries relative to surplus countries. ${ }^{10}$ In particular, output may be disrupted by a sudden stop or reversal in capital flows on countries operating with large deficit positions. We do not include the ratio of short-term debt to reserves in the baseline specification, because - as discussed in Section III - that would involve dropping advanced economies from the sample. The sub-section on robustness checks discusses the implications of including this variable in the regression.

We also include two dummy variables capturing the nature of the de facto exchange rate regime in 2007. The idea here is to investigate whether countries with pegged exchange rate regimes were more vulnerable to the sudden stop in capital flows and trade disruptions than countries with more exchange rate flexibility (in line with the vast literature on emerging market crises).

We also explore the contribution of measures of the overall size of cross-border financial activity, by including in the regression the gross scale of the international balance sheet measured at the end of 2007, as captured by the indicator $I F I=(F A+F L) / G D P$. This measure has been widely used in previous empirical research. ${ }^{11}$ The size of cross-border investment positions represents an important financial transmission mechanism. A country's direct exposure to a decline in asset values in a given market varies in proportion to the scale of its holdings in that market. Similarly, disruption in a particular credit market has the most direct impact on the biggest issuers of liabilities in that market. However, a larger international balance sheet may also provide valuable diversification in the event of instability in the domestic financial system. A country is less exposed to declines in domestic asset values to the extent that it has issued claims on domestic assets to foreign investors and reduced domestic holdings in favor of a more internationally diversified asset portfolio. Accordingly, it is not clear on an ex-ante basis whether a larger international balance sheet should be associated with a greater or lesser exposure to the global crisis. We enter this variable in log form, in view of the skewed nature of the cross-

\footnotetext{
${ }^{10}$ We also experimented with the inclusion of the net foreign asset position, as discusses in the sub-section on robustness.

${ }^{11}$ Recent examples include Kose et al (2009a, 2009b).
} 
sectional distribution of this variable, with a small number of international financial centers showing very large values for this variable. ${ }^{12}$

Finally, we include the level of GDP per capita, the GDP growth rate over 2005-2007, and the trend growth rate, proxied by the average growth rate over the period 1990-2007 (1995-2007 for countries in Central and Eastern Europe and the former Soviet Union). The level of GDP per capita is included since financial development indicators are correlated with the overall level of economic development, and to the extent possible we want to differentiate between financial factors and factors related to the general level of development. The trend growth rate is included so as to take into account persistent differences in growth across countries - something particularly important in such a diverse sample. The growth rate over 2005-2007 is instead a control for above-trend growth during the pre-crisis period. As noted earlier, the specification encompasses different measures of growth slowdowns: the decline in growth rate relative to trend and the decline in growth rate over the previous 3 years.

We report results for the full sample of countries (column 1); in addition, we also estimate the specifications for subsamples that exclude oil exporters (column 2 and 5), low-income countries, using a threshold of $\$ 1000$ for 2007 GDP per capita (column 3, 4, and 5), small financial centers (columns 4 and 5). The rationales of excluding low-income countries are data-quality issues, as well as the fact that low-income countries rely more heavily on official forms of international finance and are less exposed to private-sector financial flows. The rationale for excluding small financial centers is the fact that variables related to financial openness and, in some cases, net foreign assets take extreme values, complicating statistical inference.

Table 6a displays the results for the output slowdown. In order to ease the interpretation of coefficient sizes, the growth rates (on both sides of the equation) are expressed as percentage points, while the remaining variables that are ratios to GDP are expressed in percent. Thus, for example, if the sum of imports and exports prior to the crisis is 50 percent of GDP higher, growth during the crisis is lower by around 0.4 percentage points, and if the share of manufacturing to GDP is 10 percentage points higher, growth is lower by about $0.4-0.5$ percentage points.

In relation to the full sample results, column (1) of Table 6a broadly confirms the results of the analysis presented in the previous section. Namely, growth during the crisis was lower in countries with higher income per capita, high pre-crisis credit growth, and current account deficits. Higher trade openness is negatively correlated with output performance during the crisis, but the partial correlation is not statistically significant. The results also indicate that there is a weak correlation between growth during the crisis period and both growth during 2005-2007 and trend growth - in other words, growth declines (relative to pre-crisis growth rates) were larger in countries that were growing faster prior to the crisis. ${ }^{13}$ Also, once we control for GDP per capita and the current account, there is no evidence that "financial openness" (the size of the

\footnotetext{
${ }^{12}$ Furthermore, we exclude Luxembourg from all the regressions, given the very extreme level of IFI for this country, as well as Equatorial Guinea, for overall problems with data quality.

${ }^{13}$ The correlation of "trend" growth with growth during 2005-07 is in general positive and strong.
} 
external balance sheet) is associated with lower growth during the crisis. Indeed, this variable is significant only in column (3) and it enters with a positive sign in that case.

Results are generally robust to changes in sample specification (columns 2-5). The main exceptions relate to the exclusion of financial centers: the economic and statistical significance of trade openness declines (in line with the fact that growth was weaker in financial centers, which are very open to trade) and the economic significance of the credit growth variable increases further. We also find some evidence that countries with a de facto pegged exchange rate regime prior to the crisis experienced lower growth during the crisis. ${ }^{14}$

Overall, the explanatory power of the regressions reported in Table 6a is reasonable, particularly in light of the heterogeneity in the sample and the exclusive reliance on pre-crisis variables, with adjusted $\mathrm{R}^{2}$ above 0.4 . There are clearly several important factors that are affected economic performance during 2008-09 and that are not captured by pre-crisis variables. Among those are economic outcomes in trading partners (given trade and financial spillovers) as well as a country's policy response to the crisis. In Table $6 \mathrm{~b}$ we investigate whether the component of growth during 2008-2009 that is not explained by pre-crisis variables can be related to growth outcomes in trading partners during the crisis period. These outcomes can affect countries through the trade channel, as well as through financial linkages (that are strongly correlated with trade linkages). ${ }^{15}$ The results clearly indicate a strong link between residuals and output performance in trading partners: a 1 percentage point decline in growth in trading partners relative to the pre-crisis period is associated with a 0.9 percentage points decline in growth in the home country.

It is much more difficult to look at the effects of the policy response on output performance. While the use of residuals from a regression including only pre-crisis variables can help in principle help alleviate the problem of reverse causality, there are very severe problems in developing a consistent measure of "policy response" across such a large sample of countries. ${ }^{16}$ In particular, measures of the change in the structural fiscal balance are only available for a small subset of the countries in our sample. Overall, in results not reported, we find no evidence of a robust relation between growth over 2008-09 and the change in the fiscal balance between 200809 and 2005-07.

\footnotetext{
${ }^{14}$ This evidence is somewhat stronger statistically when oil exporters are excluded-these countries had stronger growth during 2008-09 and tend to have a pegged exchange rate regime.

${ }^{15}$ It is unfortunately not possible to construct a reliable measure of bilateral financial linkages for such a large sample of countries. Note also that many available measures of bilateral financial linkages rely on residence-based statistics (the residence principle being the one adopted for the balance of payments). As a result, these statistics overstate considerably the importance of financial centers as financial trading partners, and fail to capture linkages that can occur through bank affiliate entities that are resident in one country but belong to a banking group from a different country.

${ }^{16}$ Our regressions are reduced form. The policy response may also operate by affecting the coefficients on the precrisis variables to the extent that policy responds systematically to the values of these pre-crisis variables.
} 
In Table 7a, we present a similar set of regressions to explain the growth rate of domestic demand during 2008-09. Overall, results are similar to those presented in Table 6a, and the fit of the regressions is also similar. In particular, the link between demand growth during the crisis on the one hand, and pre-crisis demand growth and trend demand growth on the other hand, is economically weak and generally statistically insignificant, implying much larger demand growth declines (relative to pre-crisis growth rates) in countries where demand had been rising rapidly pre-crisis. Also, the coefficient on the current account balance is now considerably higher and always strongly significant - countries with large current account deficits in the pre-crisis period experienced sharper declines in domestic demand. Holding other variables constant, a current account deficit larger by 5 percentage points of GDP is associated with a decline in demand growth which is 1 percentage point larger - an economically significant effect. Similarly, the coefficient on private credit growth is higher: higher pre-crisis credit growth is associated with a stronger demand slowdown during the crisis.

In contrast with the output regressions, we find no evidence that pegged exchange rate regimes are associated with a sharper decline in domestic demand. It is also interesting to note that a high share of manufacturing output in GDP is associated with lower demand growth during the crisis. The economic and statistical significance of this variable declines when oil exporters are excluded: this happens because oil exporters experienced stronger demand growth during the crisis period and have a lower share of manufacturing output in GDP (around 10 percent) relative to the other countries in the sample (where it averages 14-16 percent, depending on sample composition).

Symmetrically to Table $6 \mathrm{~b}$, Table $7 \mathrm{~b}$ explores whether the unexplained component of demand growth during the crisis is associated with economic performance in trading partners during that period. Again the answer is yes-demand growth is on average 1 percentage point lower in countries where trading partners' output declined by 1 percentage point relative to the pre-crisis period.

In sum, the empirical results emphasize the "advanced economies nature" of the crisis, as well as the importance for explaining the decline in output and demand growth rates of various measures of buoyancy of economic activity pre-crisis (such as the increase in the ratio of credit growth to GDP), external vulnerabilities (larger current account deficits), and exposure to trade and production of traded goods.

\section{B. Robustness checks}

In addition to the results presented in Tables $6 \mathrm{a}$ and $7 \mathrm{a}$ we have experimented with a variety of other pre-crisis control variables in our regression analysis. In particular, we have included various measures of short-term debt (scaled by GDP or by foreign exchange reserves). In a sample of 29 emerging markets, Blanchard, Faruqee, and Das (2010) find this variable to be strongly correlated with the intensity of the output decline in 2008-09. While we find evidence of a significant negative correlation between short-term debt as a ratio of GDP and the decline in growth over 2008-09 relative to 2005-07 for that 33-country sample, the results do not carry through to our larger sample. We have also considered specifications that include short-term debt 
at remaining maturity as a ratio of foreign exchange reserves. ${ }^{17}$ This variable is strongly correlated with the change in the ratio of private credit to GDP as well as with GDP per capita. Its conditional correlation with output and demand growth in 2008-2009 is negative, but not statistically significant.

We have also ran specifications of the baseline regressions in Tables $6 \mathrm{a}$ and $7 \mathrm{a}$ including stock measures of net external exposures, such as net foreign assets as a ratio of GDP as well as their breakdown between net equity and net debt positions. In the data these variables are strongly collinear with the current account balance variable. If that variable is excluded, the coefficient on the ratio of net foreign assets to GDP is positive and statistically significant in both the output growth and especially the demand growth regressions, consistent with the results on the role of the current account balance. If net foreign assets are split into net debt and net equity, the coefficients on both are similar. Overall, we interpret these results as further proof of the importance of pre-crisis net external vulnerabilities in explaining output growth during the crisis, whether measured in terms of net flows or accumulated net positions.

In related fashion, we experimented with the inclusion of the net external asset position vis-à-vis BIS reporting banks (measured on a locational basis) scaled by GDP, in view of the central role played by the international banking system in the origination and propagation of the global crisis. It turns out that this variable (whether measured as the ratio at the end of 2007 or as the change in the ratio between end-2004 and end-2007) is highly collinear with the growth rate of private credit during the pre-crisis period (the correlation is around -0.7 if small financial centers are excluded). In most specifications, the joint inclusion of either BIS variable and the private credit variable renders both individually insignificant even if each is strongly significant when entered on its own. So, if the growth in private credit is excluded, countries with a worse net position visà-vis BIS-reporting banks, or a worsening of that position during 2005-2007, had significantly lower growth during the crisis period. We interpret the BIS variable as proxying for one mechanism by which pre-crisis private credit expansion may have affected macroeconomic dynamics during the crisis, in terms of raising vulnerability to a shift in external credit conditions. Further investigation of this hypothesis is a topic for future research.

Finally, among other pre-crisis variables, we have also included in the regression a measure of output volatility over the period 1990-2007, but this variable was economically and statistically not significant. Finally, another possible concern is that our results could be influenced by developments in a number of very small countries. To address this concern, we have re-run the regressions presented in Tables $6 \mathrm{a}$ and $7 \mathrm{a}$ as weighted least squares, with weights proportional to the size of the economy (GDP in U.S. dollars). The results are broadly unchanged relative to those presented earlier.

\footnotetext{
${ }^{17}$ International Monetary Fund, 2010 finds the ratio of reserves to short-term debt plus the current account deficit to be significantly and positively correlated with the change in real output between peak and trough for emerging markets during the crisis.
} 


\section{International Smoothing}

While the decline in output and demand growth are certainly key indicators of the macroeconomic impact of the crisis, the theoretical literature also heavily emphasizes that international financial integration may facilitate international risk sharing, with domestic consumption insulated from the country-specific component of domestic GDP fluctuations. On the other hand, financial integration also implies that domestic consumption will be affected by international wealth shocks even if domestic GDP is unaffected.

In addition to the risk sharing dimension, it is also important to take into account that an increase in risk aversion and a tightening of lending standards were central features of the global credit crisis. Accordingly, it is plausible that there has been a shift in the ability to borrow, with a requirement that deficit countries rebuild the value of their net external positions. Put differently, such a shift in credit conditions may militate against intertemporal smoothing since those countries that may wish to borrow find the cost of credit too high or are rationed out of the market.

For these reasons, we also run a second set of regressions where the dependent variable is the growth rate of consumption over 2008-2009. In particular, we examine how measures of international financial integration and creditworthiness affected consumption growth during the crisis period.

Our general specification can be written as

$$
\hat{C}_{i}=\alpha+\beta \hat{Y}_{i}+\sigma I F I_{i}+\theta I F I_{i} * \hat{Y}_{i}+\chi V U L N_{i}+\varepsilon_{i}
$$

where $\hat{C}_{i}$ is the consumption growth rate over 2008-2009, $\hat{Y}_{i}$ is the output growth rate, $I F I_{i}$ is a measure of international financial integration and $V U L N_{i}$ are measures of net financial vulnerability. ${ }^{18}$ In relation to financial vulnerability, we consider two main measures of exposure to credit markets: the current account balance in 2007 (in percent of GDP) and the increase in the ratio of private credit to GDP during 2004-2007.

We include the output growth rate, since a natural benchmark under limited financial integration is that consumption growth should be highly correlated with output growth. For international financial integration, we use a dummy variable that takes the value of 1 if the sum of external financial assets and liabilities is over 150 percent of GDP and the country is not a large net debtor. ${ }^{19}$ We estimate whether IFI and VULN measures directly co-move for consumption

\footnotetext{
${ }^{18}$ It is worthwhile to highlight that this specification is fundamentally different to those explored in the previous section. In Tables 6 and 7, the goal was to investigate the co-movement between pre-crisis variables and output or demand growth during the crisis. In contrast, the goal in this section is to investigate the co-movement between output growth during the crisis and consumption growth or demand growth during the crisis, controlling and interacting for a set of initial conditions in relation to financial integration and creditworthiness.

${ }^{19}$ We use a threshold of -50 percent of GDP for the net external position, so as to avoid counting as highly financially integrated those countries that have large net external liabilities as a ratio of GDP. We discretize the IFI
} 
growth. In addition, we interact the IFI measure with the output growth rate in order to assess whether higher integration reduces or amplifies the co-movement of domestic consumption growth with domestic output growth. To the extent that a high level of international financial integration means that foreign investors share domestic output risk, we would expect consumption growth to be less correlated with GDP fluctuations. If access to credit and the cost of credit disproportionately deteriorated for countries running current account deficits and that experienced rapid credit growth during 2004-2007, we would expect to observe lower consumption growth in these countries.

The results for the consumption growth regressions are presented in Table $8 .{ }^{20}$ As in Tables 6 and 7, we report results for five cuts of the data, with the full sample included in columns (1), oil exporters excluded in columns 2 and 5, low-income countries excluded in column 3 and 5, and financial centers excluded in columns 4 and 5.

Overall, results clearly point to a very strong correlation between consumption growth and GDP growth, consistent with a globally-incomplete level of international financial integration. We also find little evidence that the link between output growth and consumption growth is weaker in more financially integrated countries, since the interaction term is not significant in any of the regressions. The financial openness dummy is significantly positive in column (3) - for this sample split, greater financial integration is associated with more rapid consumption growth. However, this direct effect is not significant in the other sample splits. Table 8 also shows that the vulnerability indicators (the pre-crisis levels of the current account balance and the rate of private credit growth) had no impact on private consumption growth, beyond their influence on GDP growth.

Finally, the existence of financial frictions means that wealth shocks may also affect other types of domestic demand (investment, inventories, and the government sector). For instance, the state of corporate balance sheets may affect investment decisions. In addition, tax revenues and funding costs for public debt may be adversely affected by a decline in wealth. Accordingly, we also run a third set of regressions that adopt the same format as for the consumption equations but with the growth rate in total domestic demand as the dependent variable

$$
\hat{D}_{i}=\alpha+\beta \hat{Y}_{i}+\sigma I F I_{i}+\theta I F I_{i} * \hat{Y}_{i}+\chi V U L N_{i}++\varepsilon_{i}
$$

where $\hat{D}_{i}$ is the growth rate of total domestic demand over 2008-2009.

These results are reported in Table 9, which has the same format as Table 8. Again, there is a very strong correlation between demand growth and GDP growth. In column (2), the interaction

variable, since we do not consider that the crude measure of the gross scale of the international balance sheet affects risk sharing in a linear fashion. Rather, in this case, we simply seek to make a distinction between 'more financially integrated' and 'less financially integrated' economies.

${ }^{20}$ We also ran the 'perfect risk sharing' equation by which the cross-country variation in consumption growth should be proportionate to real exchange rate dynamics: however, the pattern is that faster consumption growth is associated with real appreciation, in violation of the benchmark hypothesis. 
term between GDP growth and the financial openness dummy is significantly negative, which is consistent with financial integration providing some insulation from the idiosyncratic component of GDP growth. However, this interaction term is not significant for the other sample splits, nor is the financial openness dummy directly significant.

In contrast to Table 8, there is strong evidence that larger pre-crisis current account deficits and high growth rates in private credit are associated with a larger decline in domestic demand, holding GDP growth constant. This finding is consistent with a tightening of credit constraints on current account deficit countries and on countries that experienced fast credit growth, leading to a correction in net external borrowing during the crisis period. Since these factors were not significant in the consumption regressions, this implies they operated primarily via investment and government spending.

\section{CONCLUding REMARKS}

Our goal in this paper has been to establish the extent to which various pre-crisis measures help explain the cross-country variation in the macroeconomic incidence of the crisis. We find a strong link between pre-crisis domestic financial factors (fast private credit growth) and external imbalances (current account deficits) on the one hand and the decline in the growth rate of output and especially domestic demand during the crisis on the other hand. Real-side variables such as trade openness and the manufacturing share are also correlated with the output and demand declines, consistently with the higher cyclicality of manufactured goods and the dramatic decline in international trade that took place during the crisis, but the conditional correlations are not always significant. The "advanced economies nature" of the crisis is highlighted by the negative correlation between GDP per capita and the decline in output growth. We also find some evidence that countries with pegged exchange regimes experienced weaker output growth during the crisis. Overall, the results of our analysis explaining growth performance during the global crisis are clearly reminiscent of the results of the literature on crises in emerging markets, that identifies external vulnerabilities (such as large current account deficits) and domestic credit booms as factors helping explain the likelihood of a crisis.

One limitation of our approach is that it does not establish the mechanisms by which these variables may have affected macroeconomic outcomes. For instance, it clearly matters whether and how initial conditions prior to the onset of the crisis affected macroeconomic policy responses during the crisis. Moreover, it would be also informative to gain a more precise understanding of the channels by which shifts in international capital market conditions affected access to credit and the cost of credit. To this end, Cetorelli and Goldberg (2010) provide interesting evidence on the role of global banking groups in the international transmission of financial shocks but much remains to be established concerning the drivers of gross and net capital flows and the re-pricing of risk during the crisis. In particular, a high priority for future research is to understand how differential exposures in international credit markets affected the macroeconomic incidence of the global recession, in view of the central role played by credit market shocks and the banking sector in the global crisis.

A second avenue for future research is to explain the differences across countries and across regions in terms of the accumulation of macroeconomic imbalances and macroeconomic vulnerabilities during the pre-crisis period. Giannone et al (2010) provide suggestive evidence 
that differences in credit market regulation were a contributory factor, while Lane and MilesiFerretti (2008) have emphasized that the nature of cross-border financial integration was very different between the advanced and emerging/developing country groups. Accordingly, we view it as important to make further progress in further understanding the economic and institutional factors that explain why some countries and regions were more exposed than others at the onset of the global financial crisis.

Finally, a third avenue for future research is an investigation of how crisis outcomes were shaped by the policy response during the crisis period. This is clearly a very important but difficult subject - researchers will have to wrestle with thorny causality issues as well as the difficulty of defining measures of policy responses that are comparable across countries. 


\section{References}

Acharya, Viral, Philipp Schnabl, and Gustavo Suarez, 2009, "Securitization without Risk Transfer," mimeo, New York University, November.

Beck, Thorsten, Asli Demirgüç-Kunt and Ross Levine, (2000), "A New Database on Financial Development and Structure," World Bank Economic Review 14, 597-605.

Beck, Thorsten and Asli Demirgüç-Kunt (2009), "Financial Institutions and Markets Across Countries and over Time: Data and Analysis", World Bank Policy Research Working Paper No. 4943, May.

Berglof, Erik, Yevgeniya Korniyenko, Alexander Plekhanov and Jeromin Zettelmeyer (2009), "Understanding the Crisis in Emerging Europe," mimeo, EBRD.

Berkmen, Pelin, Gaston Gelos, Robert Rennhack, and James P. Walsh (2009), "The Global Financial Crisis: Explaining Cross-Country Differences in the Output Impact," IMF Working Paper 09/280.

Blanchard, Olivier, Hamid Faruqee, and Mitali Das (2010), "The Initial Impact of the Crisis on Emerging Market Countries," Brookings Papers on Economic Activity, forthcoming.

Brunnermeier, Markus (2009), "Deciphering The Liquidity and Credit Crunch 2007-2008," Journal of Economic Perspectives 23(1), 77-100.

CES Ifo (2009), "The Financial Crisis", in The EEAG Report on The European Economy 2009, Munich, Germany: CES Ifo.

Cetorelli, Nicola and Linda S. Goldberg (2010), "Global Banks and International Shock Transmission: Evidence from the Crisis," IMF Economic Review 58(2), forthcoming.

Devereux, Michael B. and James Yetman (2010), "Financial De-Leveraging and the International Transmission of Shocks," Hong Kong Institute for Monetary Research Working Paper No. 13.

Giannone, Domenico, Michele Lenza and Lucrezia Reichlin (2010), "Market Freedom and the Global Recession," IMF Economic Review 58(2), forthcoming.

Gupta, Poonam, Deepak Mishra and Ratna Sahay (2007), "Behavior of output during currency crises," Journal of International Economics 72, Issue 2, July, pp. 428-450.

Imbs, Jean (2010), “The First Global Recession in Decades," IMF Economic Review 58(2), forthcoming.

International Monetary Fund, Annual Report on Exchange Arrangements and Exchange Restrictions, Washington DC: International Monetary Fund. 
International Monetary Fund, 2010, "How Did Emerging Markets Cope in the Crisis?" International Monetary Fund Policy Paper, Washington DC (http://www.imf.org/external/np/pp/eng/2010/061510.pdf)

Kamin, Steven B. and Laurie Pounder DeMarco (2010), "How Did a Domestic Housing Slump Turn into a Global Financial Crisis?," Federal Reserve Board, International Finance Discussion Paper 2010-994, January.

Kaminsky, Graciela and Carmen Reinhart (1999), "The twin crises: the causes of banking and balance-of-payments problems," American Economic Review 89 no. 3 (June), 473-500.

Kose, Ayhan, Eswar Prasad and Marco Terrones (2009a), "Does Financial Globalization Promote International Risk Sharing?," Journal of Development Economics vol. 89 no. 2, July, pp. 258-270.

Kose, Ayhan, Eswar Prasad and Marco Terrones (2009b), "Does Openness to International Financial Flows Raise Productivity Growth?," Journal of International Money and Finance Vol. 28 no. 4, June, pp. 554-580.

Krugman, Paul (2008), “The International Finance Multiplier,” mimeo, Princeton University.

Lane, Philip R., and Gian Maria Milesi-Ferretti, 2007, "The External Wealth of Nations Mark II," Journal of International Economics 73 no. 2 (November), 223-250.

Lane, Philip R., and Gian Maria Milesi-Ferretti, 2008, "The Drivers of Financial Globalization," American Economic Review 98 (2), 327-332.

Milesi-Ferretti, Gian Maria (2009), "The International Transmission of the Financial Crisis," mimeo, International Monetary Fund, November.

Milesi-Ferretti, Gian Maria and Assaf Razin (2000), "Current Account Reversals and Currency Crises: Empirical Regularities," in Currency Crises, edited by Paul Krugman, Chicago: University of Chicago Press for NBER.

Rose, Andrew and Mark Spiegel (2009a), "The Causes and Consequences of the 2008 Crisis: Early Warning," Global Journal of Economics, forthcoming.

Rose, Andrew and Mark Spiegel (2009b), "The Causes and Consequences of the 2008 Crisis: International Linkages and American Exposure," Pacific Economic Review, forthcoming. 
Appendix 1. List of Economies

\begin{tabular}{|c|c|c|c|c|}
\hline Albania & Costa Rica & India & Mozambique & Sri Lanka \\
\hline Algeria & Côte d'Ivoire & Indonesia & Myanmar & St. Kitts and Nevis \\
\hline Angola & country & Iran & Namibia & St. Lucia \\
\hline Antigua and Barbuda & Croatia & Ireland & Nepal & St. Vincent \& Gr. \\
\hline Argentina & Cyprus & Israel & Netherlands & Sudan \\
\hline Armenia & Czech Republic & Italy & New Zealand & Swaziland \\
\hline Australia & Denmark & Jamaica & Nicaragua & Sweden \\
\hline Austria & Djibouti & Japan & Niger & Switzerland \\
\hline Azerbaijan & Dominica & Jordan & Nigeria & Syria \\
\hline Bahrain & Dominican Rep. & Kazakhstan & Norway & Taiwan prov. of China \\
\hline Bangladesh & Ecuador & Kenya & Oman & Tajikistan \\
\hline Belarus & Egypt & Kiribati & Pakistan & Tanzania \\
\hline Belgium & El Salvador & Korea & Panama & Thailand \\
\hline Belize & Equatorial Guinea* & Kuwait & Papua New Guinea & Togo \\
\hline Benin & Eritrea & Kyrgyz Republic & C Paraguay & Tonga \\
\hline Bhutan & Estonia & Laos & Peru & Trinidad \& Tobago \\
\hline Bolivia & Ethiopia & Latvia & Philippines & Tunisia \\
\hline $\begin{array}{l}\text { Bosnia and } \\
\text { Herzegovina }\end{array}$ & Fiji & Lebanon & Poland & Turkey \\
\hline Botswana & Finland & Lesotho & Portugal & Turkmenistan \\
\hline Brazil & France & Liberia & Qatar & Uganda \\
\hline Brunei Darussalam & Gabon & Libya & Romania & Ukraine \\
\hline Bulgaria & Gambia, The & Lithuania & Russia & Un. Arab Emirates \\
\hline Burkina Faso & Georgia & Luxembourg* & Rwanda & United Kingdom \\
\hline Burundi & Germany & Macedonia & Samoa & United States \\
\hline Cambodia & Ghana & Madagascar & São Tomé \& Príncipe & Uruguay \\
\hline Cameroon & Greece & Malawi & Saudi Arabia & Uzbekistan \\
\hline Canada & Grenada & Malaysia & Senegal & Vanuatu \\
\hline Cape Verde & Guatemala & Maldives & Serbia & Venezuela \\
\hline Central African Rep. & Guinea & Mali & Seychelles & Vietnam \\
\hline Chad & Guinea-Bissau & Malta & Sierra Leone & Yemen \\
\hline Chile & Guyana & Mauritania & Singapore & Zambia \\
\hline China,P.R.: Mainland & Haiti & Mauritius & Slovak Republic & Zimbabwe \\
\hline Colombia & Honduras & Mexico & Slovenia & \\
\hline Comoros & $\begin{array}{l}\text { Hong Kong S.A.R. of } \\
\text { China }\end{array}$ & Moldova & Solomon Islands & \\
\hline Congo, Dem. Rep. of & Hungary & Mongolia & South Africa & \\
\hline Congo, Republic of & Iceland & Morocco & Spain & \\
\hline
\end{tabular}

* Excluded from the regressions presented in Tables 6-9. 
Appendix 2. Data Definitions and Sources

GDP and domestic demand variables: IMF, World Economic Outlook database, April 2010.

Trade openness: Sum of imports and exports of goods and services over GDP. Source: IMF, World Economic Outlook.

Manufacturing share: Share of manufacturing output in total output. Source: United Nations.

Private Credit / GDP and change in private credit/GDP: World Bank Financial Structure database (Beck, Demirgüç-Kunt and Levine (2000, 2009) and authors' calculations based on IMF, International Financial Statistics.

Financial openness: Sum of external assets and liabilities over GDP. Source: Lane and MilesiFerretti, External Wealth of Nations database.

Output volatility: Standard deviation of output growth over the period 1990-2007 (1995-2007 for some countries in Central and Eastern Europe and the former Soviet Union).

Debt/GDP (gross): sum of debt assets (including reserves) and liabilities divided by GDP, 2007. Source: Lane and Milesi-Ferretti, External Wealth of Nations database.

Net Debt/GDP: difference between debt assets (including reserves) and debt liabilities, divided by GDP, 2007. Source: Lane and Milesi-Ferretti, External Wealth of Nations database.

NFA/GDP: Net foreign asset position divided by GDP, 2007. Source: Lane and Milesi-Ferretti, External Wealth of Nations database.

BIS net /GDP: net position vis-à-vis BIS-reporting banks, December 2007. Source: BIS, locational banking statistics.

Trade with US/GDP: exports plus imports vis-à-vis the United States. Source: United States Bureau of Economic Analysis.

De facto peg: dummy variable taking the value of 1 for countries with a de facto pegged exchange rate regime in 2007 and zero otherwise. Source: International Monetary Fund, Annual Report on Exchange Rate Arrangements and Exchange Restrictions.

Intermediate exchange rate regime: dummy variable taking the value of 1 for countries with a de facto intermediate exchange rate regime in 2007 and zero otherwise. Source: International Monetary Fund, Annual Report on Exchange Rate Arrangements and Exchange Restrictions.

Foreign exchange reserves: Source: IMF, International Financial Statistics.

Short-term debt: Sources: IMF, World Economic Outlook database (emerging and developing countries) and BIS-IMF-World Bank "debt hub" database (advanced economies). 
Short-term debt, remaining maturity: Sources: IMF, World Economic Outlook database. 
Table 1. The Geographical Impact of the Crisis (I)*

A. Changes in growth (2008-09 minus 2005-2007)

\begin{tabular}{|lrrrrrrrr|}
\hline Country group $\rightarrow$ & $\begin{array}{r}\text { Emerg. } \\
\text { Europe }\end{array}$ & CIS & $\begin{array}{r}\text { Emerg. } \\
\text { Asia }\end{array}$ & $\begin{array}{r}\text { Central } \\
\text { and Latin } \\
\text { America }\end{array}$ & Carib. & Africa & Indust. & $\begin{array}{r}\text { Middle } \\
\text { East \& }\end{array}$ \\
Crisis intensity $\downarrow$ & 10 & 2 & 1 & 2 & 1 & 1 & 3 & 0 \\
Worst 20 & 13 & 3 & 1 & 4 & 1 & 2 & 6 & 0 \\
Berst 20 & 1 & 0 & 1 & 2 & 0 & 12 & 0 & 4 \\
Best 30 & 1 & 0 & 2 & 3 & 0 & 20 & 0 & 4 \\
\hline
\end{tabular}

B. Growth rate 2008-09

\begin{tabular}{|lrrrrrrrr|}
\hline Country group $\rightarrow$ & $\begin{array}{r}\text { Emerg. } \\
\text { Europe }\end{array}$ & CIS & $\begin{array}{r}\text { Emerg. } \\
\text { Asia }\end{array}$ & $\begin{array}{r}\text { Central } \\
\text { and Latin } \\
\text { America }\end{array}$ & Carib. & Africa & Indust. & $\begin{array}{r}\text { Middle } \\
\text { East \& } \\
\text { Crisis intensity } \downarrow\end{array}$ \\
Worst 20 & 8 & 0 & 0 & 2 & 0 & 1 & 9 & 0 \\
Worst 30 & 11 & 1 & 1 & 3 & 1 & 1 & 12 & 0 \\
Best 20 & 0 & 1 & 4 & 1 & 0 & 10 & 0 & 4 \\
Best 30 & 0 & 1 & 7 & 1 & 0 & 14 & 0 & 7 \\
\hline
\end{tabular}

* The table lists the number of countries among the most affected and least affected by the crisis. The crisis measure is obtained by constructing a global ranking for each of several crisis measures (growth in output, demand, private and public consumption, investment, exports, imports) and averaging the rankings.

Africa: Angola, Benin, Botswana, Burkina Faso, Burundi, Cameroon, Cape Verde, Central African Rep., Chad, Comoros, Congo, Dem. Rep. of, Congo, Republic of, Côte d'Ivoire, Djibouti, Equatorial Guinea, Eritrea, Ethiopia, Gabon, Gambia, Ghana, Guinea, Guinea-Bissau, Kenya, Lesotho, Liberia, Madagascar, Malawi, Mali, Mauritania, Mauritius, Mozambique, Namibia, Niger, Nigeria, Rwanda, São Tomé \& Príncipe, Senegal, Seychelles, Sierra Leone, South Africa, Sudan, Swaziland, Tanzania, Togo, Uganda, Zambia, Zimbabwe.

Caribbean: Antigua and Barbuda, Aruba, Belize, Dominica, Grenada, Guyana, Jamaica, St. Kitts and Nevis, St. Lucia, St. Vincent \& Grenadines, Trinidad and Tobago.

Central and Latin America: Argentina Bolivia, Brazil, Chile, Colombia, Costa Rica, Dominican Rep., Ecuador, El Salvador, Guatemala, Haiti, Honduras, Mexico, Nicaragua, Panama, Paraguay, Peru, Uruguay, Venezuela, Rep. Bol. Commonwealth of Independent States (CIS): Armenia, Azerbaijan, Georgia, Kazakhstan, Kyrgyz Republic, Russia, Tajikistan, Turkmenistan, Uzbekistan, plus Mongolia.

Emerging Asia: Bangladesh, Bhutan, Brunei Darussalam, Cambodia, China, Fiji, Hong Kong S.A.R., India, Indonesia, Kiribati, Korea, Lao People's Dem.Rep, Macao S.A.R., Malaysia, Maldives, Myanmar, Nepal, Pakistan, Papua New Guinea, Philippines, Samoa, Singapore, Solomon Islands, Sri Lanka, Taiwan province of China, Thailand, Timor-Leste, Tonga, Vanuatu, Vietnam.

Emerging Europe: Albania, Belarus, Bosnia and Herzegovina, Bulgaria, Croatia, Czech Republic, Estonia, Hungary, Latvia, Lithuania, Macedonia, Moldova, Poland, Romania, Serbia, Slovak Republic, Slovenia, Turkey, Ukraine.

Industrial: United States, United Kingdom, Austria, Belgium, Denmark, France, Germany, Italy, Luxembourg, Netherlands, Norway, Sweden, Switzerland, Canada, Japan, Finland, Greece, Iceland, Ireland, Malta, Portugal, Spain, Australia, New Zealand, Cyprus, Israel.

Middle East and North Africa: Bahrain, Iran, Jordan, Kuwait, Lebanon, Oman, Qatar, Saudi Arabia, Syrian Arab Republic, United Arab Emirates, Egypt, Yemen, Republic of, Algeria, Libya, Morocco, Tunisia. 
Table 2. The Geographical Impact of the Crisis (II)

A. Average change in growth rates

\begin{tabular}{|lrrrrrrr|}
\hline & Output & Demand & Priv. cons. & Pub. Cons. & Invest. & Exports & Imports \\
Emerging Europe & -7.8 & -12.0 & -8.7 & -1.2 & -25.6 & -13.0 & -19.9 \\
CIS & -7.3 & -14.0 & -6.6 & -0.9 & -25.2 & -6.8 & -7.1 \\
Caribbean & -5.3 & -6.5 & -5.4 & -5.5 & -6.9 & -8.0 & -9.5 \\
Industrial & -4.6 & -5.4 & -3.4 & 0.2 & -15.3 & -10.8 & -13.1 \\
Western Hem. & -3.7 & -5.6 & -4.3 & -1.0 & -11.8 & -7.5 & -13.8 \\
Emerging Asia & -3.1 & -4.5 & -1.0 & -1.5 & -11.8 & -7.6 & -5.9 \\
Africa & -1.9 & -0.1 & 1.8 & 1.7 & 0.9 & -4.1 & -1.4 \\
Middle East & -1.4 & -1.4 & -0.7 & -2.9 & -2.7 & -8.2 & -6.7 \\
\hline
\end{tabular}

B. Average growth rates

\begin{tabular}{|lrrrrrrr|}
\hline & Output & Demand & Priv. cons. & Pub. Cons. & Invest. & Exports & Imports \\
Emerging Europe & -1.3 & -4.0 & -1.2 & 1.6 & -13.3 & -3.6 & -8.2 \\
Industrial & -1.3 & -1.9 & -0.3 & 2.6 & -9.6 & -5.0 & -6.4 \\
Caribbean & -0.7 & -2.9 & -4.3 & -6.6 & -3.5 & 6.3 & -7.2 \\
Western Hem. & 2.3 & 1.5 & 1.9 & 4.4 & -1.0 & -0.6 & -2.3 \\
Emerging Asia & 3.1 & 3.7 & 6.1 & 6.2 & -1.5 & -0.9 & 0.4 \\
Africa & 3.5 & 5.8 & 6.6 & 6.6 & 11.6 & 1.9 & 6.1 \\
CIS & 3.6 & -0.5 & 1.0 & 8.8 & -2.7 & -0.4 & 7.1 \\
Middle East & 4.7 & 6.8 & 7.1 & 4.8 & 7.5 & -0.4 & 5.9 \\
\hline
\end{tabular}

Source: World Economic Outlook, April 2010.

Africa: Angola, Benin, Botswana, Burkina Faso, Burundi, Cameroon, Cape Verde, Central African Rep., Chad, Comoros, Congo, Dem. Rep. of, Congo, Republic of, Côte d'Ivoire, Djibouti, Equatorial Guinea, Eritrea, Ethiopia, Gabon, Gambia, Ghana, Guinea, Guinea-Bissau, Kenya, Lesotho, Liberia, Madagascar, Malawi, Mali, Mauritania, Mauritius, Mozambique, Namibia, Niger, Nigeria, Rwanda, São Tomé \& Príncipe, Senegal, Seychelles, Sierra Leone, South Africa, Sudan, Swaziland, Tanzania, Togo, Uganda, Zambia, Zimbabwe.

Caribbean: Antigua and Barbuda, Aruba, Belize, Dominica, Grenada, Guyana, Jamaica, St. Kitts and Nevis, St. Lucia, St. Vincent \& Grenadines, Trinidad and Tobago.

Central and Latin America: Argentina Bolivia, Brazil, Chile, Colombia, Costa Rica, Dominican Rep., Ecuador, El Salvador, Guatemala, Haiti, Honduras, Mexico, Nicaragua, Panama, Paraguay, Peru, Uruguay, Venezuela, Rep. Bol. Commonwealth of Independent States (CIS): Armenia, Azerbaijan, Georgia, Kazakhstan, Kyrgyz Republic, Russia, Tajikistan, Turkmenistan, Uzbekistan, plus Mongolia.

Emerging Asia: Bangladesh, Bhutan, Brunei Darussalam, Cambodia, China, Fiji, Hong Kong S.A.R., India, Indonesia, Kiribati, Korea, Lao People's Dem.Rep, Macao S.A.R., Malaysia, Maldives, Myanmar, Nepal, Pakistan, Papua New Guinea, Philippines, Samoa, Singapore, Solomon Islands, Sri Lanka, Taiwan province of China, Thailand, Timor-Leste, Tonga, Vanuatu, Vietnam.

Emerging Europe: Albania, Belarus, Bosnia and Herzegovina, Bulgaria, Croatia, Czech Republic, Estonia, Hungary, Latvia, Lithuania, Macedonia, Moldova, Poland, Romania, Serbia, Slovak Republic, Slovenia, Turkey, Ukraine.

Industrial: United States, United Kingdom, Austria, Belgium, Denmark, France, Germany, Italy, Luxembourg, Netherlands, Norway, Sweden, Switzerland, Canada, Japan, Finland, Greece, Iceland, Ireland, Malta, Portugal, Spain, Australia, New Zealand, Cyprus, Israel.

Middle East and North Africa: Bahrain, Iran, Jordan, Kuwait, Lebanon, Oman, Qatar, Saudi Arabia, Syrian Arab Republic, United Arab Emirates, Egypt, Yemen, Republic of, Algeria, Libya, Morocco, Tunisia. 
Table 3. "Top 5" Crisis Countries

\begin{tabular}{|c|c|c|c|c|c|}
\hline \multicolumn{6}{|c|}{ Changes in growth rates (2008-2009 minus 2005-2007) } \\
\hline \multirow{3}{*}{ GDP growth } & Latvia & Azerbaijan & Armenia & Estonia & Lithuania \\
\hline & -22.5 & -18.5 & -18.0 & -17.8 & -15.0 \\
\hline & Latvia & Estonia & Ukraine & Iceland & $\begin{array}{r}\text { Solomon } \\
\text { Islands }\end{array}$ \\
\hline \multirow[t]{2}{*}{ Total demand growth } & -32.9 & -29.0 & -24.5 & -22.8 & -22.6 \\
\hline & Latvia & $\begin{array}{r}\text { Solomon } \\
\text { Islands }\end{array}$ & Estonia & $\begin{array}{r}\text { Kyrgyz } \\
\text { Republic }\end{array}$ & Ukraine \\
\hline \multirow[t]{2}{*}{ Private cons. growth } & -30.0 & -26.2 & -22.8 & -21.1 & -19.7 \\
\hline & Seychelles & Moldova & Armenia & Latvia & Iceland \\
\hline \multirow[t]{2}{*}{ Investment growth } & -69.9 & -54.1 & -53.8 & -51.5 & -51.3 \\
\hline & Angola & Botswana & Cape Verde & Turkmenistan & Togo \\
\hline \multirow[t]{2}{*}{ Export growth } & -34.0 & -30.9 & -27.3 & -24.5 & -24.3 \\
\hline & Latvia & Venezuela & Iceland & Estonia & Kenya \\
\hline \multirow[t]{3}{*}{ Import growth } & -40.9 & -40.7 & -33.5 & -33.0 & -33.0 \\
\hline & & Growth rates & $(2008-09)$ & & \\
\hline & Latvia & Estonia & Ukraine & Lithuania & Ireland \\
\hline \multirow[t]{2}{*}{ GDP growth } & -11.5 & -9.0 & -6.9 & -6.5 & -5.1 \\
\hline & Latvia & Estonia & Iceland & Lithuania & Ukraine \\
\hline \multirow[t]{2}{*}{ Total demand growth } & -19.6 & -17.5 & -14.6 & -11.9 & -9.7 \\
\hline & Latvia & Bahrain & Estonia & Iceland & $\begin{array}{r}\text { Trinidad and } \\
\text { Tobago }\end{array}$ \\
\hline \multirow[t]{2}{*}{ Priv. cons. growth } & -14.3 & -12.5 & -12.1 & -11.3 & -8.7 \\
\hline & Latvia & Iceland & Lithuania & Malta & Ireland \\
\hline \multirow[t]{2}{*}{ Investment growth } & -38.6 & -37.1 & -34.3 & -31.3 & -26.6 \\
\hline & Botswana & Turkmenistan & $\begin{array}{r}\text { Central African } \\
\text { Rep. }\end{array}$ & Japan & Italy \\
\hline \multirow[t]{2}{*}{ Export growth } & -20.8 & -19.4 & -14.0 & -12.1 & -11.8 \\
\hline & Latvia & Iceland & Kenya & Estonia & Ukraine \\
\hline Import growth & -24.6 & -21.2 & -18.4 & -18.2 & -14.6 \\
\hline
\end{tabular}

Source: World Economic Outlook, April 2010. 
Table 4. Severe Crisis and Stronger Growth Countries: full sample

\begin{tabular}{|c|c|c|c|c|c|c|}
\hline \multirow[b]{2}{*}{ Change in output growth } & $\begin{array}{r}\text { Median } \\
\text { difference } \\
\text { Change }\end{array}$ & $\begin{array}{r}\text { Mean } \\
\text { difference } \\
\text { output grc }\end{array}$ & $\begin{array}{l}\text { t-test } \\
\text { th }\end{array}$ & $\begin{array}{r}\text { Median } \\
\text { difference } \\
\text { Change i }\end{array}$ & $\begin{array}{r}\text { Mean } \\
\text { difference } \\
\text { demand }\end{array}$ & $\begin{array}{l}\text { t-test } \\
\text { wth }\end{array}$ \\
\hline & $7.5 \%$ & $7.7 \%$ & 13.0 & $5.6 \%$ & $6.0 \%$ & 7.0 \\
\hline Change in total demand growth & $6.4 \%$ & $8.6 \%$ & 5.2 & $10.5 \%$ & $15.5 \%$ & 9.4 \\
\hline GDP per capita & $-13,940$ & $-20,715$ & -5.1 & $-11,318$ & $-15,729$ & -3.6 \\
\hline mean CA 2004-07 & $2.2 \%$ & $3.3 \%$ & 1.2 & $4.5 \%$ & $5.4 \%$ & 2.2 \\
\hline Openness & $-29 \%$ & $-37 \%$ & -2.6 & -0.2 & -0.2 & -1.7 \\
\hline Share of manufacturing GDP & $-7.9 \%$ & $-5.6 \%$ & -3.6 & $-5.9 \%$ & $-5.8 \%$ & -3.7 \\
\hline Priv. credit/GDP & $-53 \%$ & $-62 \%$ & -6.2 & $-34 \%$ & $-43 \%$ & -3.9 \\
\hline growth in priv. cr. /GDP & $-11 \%$ & $-15 \%$ & -3.2 & $-13 \%$ & $-20 \%$ & -4.3 \\
\hline De facto peg & -1.0 & -0.1 & -1.0 & 0.0 & 0.0 & 0.0 \\
\hline Financial openness & $-170 \%$ & $-880 \%$ & -1.5 & $-60 \%$ & $-729 \%$ & -1.2 \\
\hline Debt/GDP (gross) & $-74.4 \%$ & $-383.2 \%$ & -1.6 & $-31.9 \%$ & $-332.0 \%$ & -1.4 \\
\hline NFA/GDP & $4.3 \%$ & $-4.4 \%$ & -0.2 & $14.0 \%$ & $26.0 \%$ & 1.7 \\
\hline Net debt/GDP & $7.7 \%$ & $-79.5 \%$ & -1.1 & $2.8 \%$ & $-53.0 \%$ & -0.7 \\
\hline BIS net /GDP & $19.6 \%$ & $23.0 \%$ & 1.4 & $23.8 \%$ & $62.5 \%$ & 3.5 \\
\hline Foreign exchange reserves/GDP & $3.8 \%$ & $1.0 \%$ & 0.2 & $0.1 \%$ & $8.7 \%$ & 1.9 \\
\hline Short-term debt (remain. Mat.)/GDP & $-8.9 \%$ & $-9.1 \%$ & -1.5 & $-11.8 \%$ & $-11.1 \%$ & -1.8 \\
\hline Short-term debt (RM) / FX reserves & $-69.3 \%$ & $-80.4 \%$ & -2.7 & $-75.2 \%$ & $-78.4 \%$ & -3.0 \\
\hline Trade with US/GDP & $0.4 \%$ & $-3.7 \%$ & -1.6 & $0.9 \%$ & $-1.0 \%$ & -0.3 \\
\hline Growth in $05-07$ relative to $1990-07$ & $-0.1 \%$ & $-0.4 \%$ & -0.9 & $-0.7 \%$ & $-1.0 \%$ & -1.4 \\
\hline
\end{tabular}

Note: The first two columns report the difference between the median and the mean of samples including the countries least affected by the crisis and those most affected. Most affected countries: countries with a decline in growth of at least 4 percentage points between 2008-09 and 2005-07 (5 percentage points for domestic demand, 3 percentage points for private consumption), and negative growth in 2008-09 (around 40 countries for each crisis sample). Least affected countries: same number of countries (around 40) with the highest value of the difference between output (demand, consumption) growth in 2008-09 and 2005-07. The third column reports a t test for the hypothesis that the sample means are equal. 
Table 5. Severe Crisis and Stronger Growth Countries: sample excluding low-income countries and financial centers

\begin{tabular}{|c|c|c|c|c|c|c|}
\hline \multirow[b]{2}{*}{ Change in output growth } & \multicolumn{3}{|c|}{$\begin{array}{l}\text { Median Mean } \\
\text { difference difference t-test } \\
\text { Change in output growth }\end{array}$} & \multicolumn{3}{|c|}{$\begin{array}{l}\text { Median Mean } \\
\text { difference difference t-test } \\
\text { Change in demand growth }\end{array}$} \\
\hline & $6 \%$ & $8 \%$ & 9.0 & $5 \%$ & $6 \%$ & 5.8 \\
\hline Change in total demand growth & $6 \%$ & $9 \%$ & 4.5 & $8 \%$ & $14 \%$ & 6.9 \\
\hline GDP per capita & $-10,460$ & $-10,944$ & -2.8 & $-7,009$ & $-8,220$ & -2.1 \\
\hline mean CA 2004-07 & $1 \%$ & $6 \%$ & 1.8 & $7 \%$ & $8 \%$ & 2.9 \\
\hline Openness & $-12 \%$ & $-8 \%$ & -0.9 & $-14 \%$ & $-18 \%$ & -2.3 \\
\hline Share of manufacturing GDP & $-9 \%$ & $-6 \%$ & -2.8 & $-7 \%$ & $-6 \%$ & -3.1 \\
\hline Priv. credit/GDP & $-33 \%$ & $-34 \%$ & -3.6 & $-17 \%$ & $-19 \%$ & -1.8 \\
\hline growth in priv. cr. /GDP & $-9 \%$ & $-11 \%$ & -3.7 & $-10 \%$ & $-12 \%$ & -4.1 \\
\hline De facto peg & -1.0 & -0.1 & -1.1 & -1.0 & -0.1 & -0.9 \\
\hline Financial openness & $-115 \%$ & $-93 \%$ & -3.3 & $-31 \%$ & $-38 \%$ & -1.2 \\
\hline Debt/GDP (gross) & $-46 \%$ & $-39 \%$ & -2.1 & $-24 \%$ & $-10 \%$ & -0.5 \\
\hline NFA/GDP & $5 \%$ & $18 \%$ & 1.1 & $21 \%$ & $34 \%$ & 2.4 \\
\hline Net debt/GDP & $25 \%$ & $21 \%$ & 1.8 & $17 \%$ & $28 \%$ & 2.5 \\
\hline BIS net /GDP & $20 \%$ & $36 \%$ & 4.4 & $21 \%$ & $30 \%$ & 3.7 \\
\hline Foreign exchange reserves/GDP & $1.4 \%$ & $3.3 \%$ & 0.8 & $-0.6 \%$ & $6.6 \%$ & 1.3 \\
\hline Short-term debt (remain. Mat.)/GDP & $-9.6 \%$ & $-6.8 \%$ & -0.9 & $-9.7 \%$ & $-8.1 \%$ & -1.1 \\
\hline Short-term debt (RM) / FX reserves & $-68.7 \%$ & $-52.2 \%$ & -1.8 & $-61.7 \%$ & $-50.9 \%$ & -2.0 \\
\hline Trade with US/GDP & $1.7 \%$ & $-2.7 \%$ & -1.0 & $1.4 \%$ & $-1.9 \%$ & -0.6 \\
\hline Growth in $05-07$ relative to $1990-07$ & $-0.2 \%$ & $-0.3 \%$ & -0.8 & $-1.0 \%$ & $-0.9 \%$ & -1.1 \\
\hline
\end{tabular}

Note: The first two columns in each panel of the figure report the difference between the median and the mean of samples including the countries least affected by the crisis and those most affected (excluding low-income countries and financial centers). Most affected countries: countries with a decline in growth of at least 4 percentage points between 2008-09 and 2005-07 (5 percentage points for domestic demand, 3 percentage points for private consumption), and negative growth in 2008-09 (around 40 countries for each crisis sample). Least affected countries: same number of countries (around 40) with the highest value of the difference between output (demand, consumption) growth in 2008-09 and 2005-07. The third column reports a t test for the hypothesis that the sample means are equal. 
Table 6a. Explaining Output Growth During The Crisis

\begin{tabular}{|c|c|c|c|c|c|}
\hline & (1) & (2) & (3) & (4) & (5) \\
\hline $\begin{array}{c}\text { Sample } \rightarrow \\
\text { Expl. Variables } \downarrow\end{array}$ & $\begin{array}{c}\text { All } \\
\text { countries }\end{array}$ & $\begin{array}{l}\text { Excl. oil } \\
\text { exporters }\end{array}$ & $\begin{array}{l}\text { Excl. low } \\
\text { income }\end{array}$ & $\begin{array}{l}\text { Excl. low } \\
\text { income and } \\
\text { fin. ctrs }\end{array}$ & $\begin{array}{l}\text { Excl. low } \\
\text { income, oil, } \\
\text { and fin. ctrs }\end{array}$ \\
\hline \multirow[t]{2}{*}{ Trade openness } & -0.70 & -0.81 & $-0.96 *$ & -0.20 & -1.13 \\
\hline & {$[0.49]$} & {$[0.51]$} & {$[0.54]$} & {$[0.90]$} & {$[1.05]$} \\
\hline \multirow[t]{2}{*}{ Share of manufacturing in GDP } & -4.58 & -2.45 & -4.01 & -4.37 & 1.01 \\
\hline & [3.62] & [3.84] & [4.18] & {$[4.51]$} & [5.23] \\
\hline \multirow[t]{2}{*}{ Oil } & 0.67 & & 1.3 & 1.25 & \\
\hline & {$[0.90]$} & & [0.92] & {$[0.88]$} & \\
\hline \multirow[t]{2}{*}{ CA/GDP, 2007} & $5.50 * * *$ & $6.11 * * *$ & $5.61 * *$ & 4.17 & $5.02 *$ \\
\hline & {$[2.07]$} & {$[2.08]$} & {$[2.34]$} & {$[2.66]$} & [2.79] \\
\hline \multirow[t]{2}{*}{ Change in priv. credit/GDP, 2004-07 } & $-3.02 * *$ & $-2.72 *$ & $-3.67 * *$ & $-7.33 * *$ & $-5.70^{*}$ \\
\hline & [1.47] & [1.49] & {$[1.73]$} & {$[3.21]$} & [3.17] \\
\hline \multirow[t]{2}{*}{ log GDP per capita } & $-1.33 * * *$ & $-1.52 * * *$ & $-1.84 * * *$ & $-1.61 * * *$ & $-2.39 * * *$ \\
\hline & {$[0.26]$} & {$[0.28]$} & {$[0.45]$} & {$[0.51]$} & {$[0.57]$} \\
\hline \multirow[t]{2}{*}{ Trend growth } & 0.21 & 0.22 & 0.26 & 0.21 & 0.26 \\
\hline & {$[0.19]$} & {$[0.21]$} & {$[0.28]$} & {$[0.31]$} & {$[0.35]$} \\
\hline \multirow[t]{2}{*}{ Growth 2005-2007 } & $0.19 *$ & 0.09 & 0.1 & 0.12 & -0.13 \\
\hline & {$[0.10]$} & {$[0.18]$} & {$[0.11]$} & {$[0.11]$} & {$[0.23]$} \\
\hline \multirow[t]{2}{*}{ Log financial openness } & 0.66 & 0.78 & $1.20 * *$ & 0.88 & 1.76 \\
\hline & {$[0.45]$} & {$[0.52]$} & [0.59] & [0.91] & [1.19] \\
\hline \multirow[t]{2}{*}{ De facto peg } & -0.95 & $-1.11^{*}$ & $-1.27^{*}$ & -1.16 & $-1.47^{*}$ \\
\hline & [0.62] & {$[0.60]$} & {$[0.76]$} & {$[0.84]$} & {$[0.88]$} \\
\hline \multirow[t]{2}{*}{ De facto intermediate e.r. regime } & -0.66 & -0.5 & -1.19 & -1.28 & -1.21 \\
\hline & {$[0.62]$} & {$[0.66]$} & {$[0.74]$} & {$[0.84]$} & {$[0.94]$} \\
\hline \multirow[t]{2}{*}{ Constant } & $9.87 * * *$ & $11.15^{* * *}$ & $12.42 * * *$ & $11.72 * * *$ & $15.20 * * *$ \\
\hline & {$[2.11]$} & {$[2.36]$} & [3.13] & [3.94] & [4.17] \\
\hline Observations & 162 & 139 & 124 & 107 & 87 \\
\hline$R^{2}$ & 0.44 & 0.47 & 0.42 & 0.41 & 0.44 \\
\hline
\end{tabular}

Note: Dependent variable in the top panel is average output growth over $2008-2009$, times $100 . * * *, * * *$ denote significance at 10,5 and 1 percent levels respectively. OLS estimation, robust standard errors. Trade openness is the sum of exports and imports divided by GDP. The manufacturing share is the ratio of manufacturing output to GDP. CA/GDP is the ratio of the 2007 current account balance to GDP. Change in private credit to GDP is the change in the ratio to GDP of private credit by banks and other financial institutions between 2004 and 2007. GDP per capita is measured in current U.S. dollars in 2007. LT growth is the average growth rate over the period 19902007 (1995-2007 for some CEE and CIS countries), times 100. Growth 2005-07 is average output growth between 2005-2007. Financial openness is the sum of external financial assets and liabilities assets divided by GDP. De facto peg (intermediate e.r. regime) is a dummy variable taking the value 1 if the country had a de facto pegged (intermediate) exchange rate regime. 
Table 6b. Growth Residuals and Change in Output Growth in Trading Partners

\begin{tabular}{|c|c|c|c|c|c|}
\hline $\begin{array}{c}\text { Sample } \rightarrow \\
\text { Expl. Variables } \downarrow\end{array}$ & $\begin{array}{l}\text { All } \\
\text { countrie }\end{array}$ & $\begin{array}{l}\text { Excl. oil } \\
\text { ex exporters }\end{array}$ & $\begin{array}{l}\text { Excl. low } \\
\text { income }\end{array}$ & $\begin{array}{l}\text { Excl. low } \\
\text { income and } \\
\text { fin. ctrs }\end{array}$ & $\begin{array}{l}\text { Excl. low } \\
\text { income, } \\
\text { oil, and } \\
\text { fin. ctrs }\end{array}$ \\
\hline \multicolumn{6}{|c|}{ Dependent variable: residual from growth regression (Table 6a) } \\
\hline \multirow[t]{2}{*}{$\begin{array}{l}\text { Change in output growth in trad. } \\
\text { part. }\end{array}$} & $0.80 * *$ & $0.77^{* *}$ & $0.91 * * *$ & $0.93 * * *$ & $0.82 * * *$ \\
\hline & {$[0.31]$} & {$[0.30]$} & {$[0.32]$} & {$[0.31]$} & {$[0.30]$} \\
\hline \multirow[t]{2}{*}{ Constant } & $3.31 * * *$ & $3.19 * * *$ & $3.87 * * *$ & $4.01 * * *$ & $3.57 * * *$ \\
\hline & {$[1.23]$} & {$[1.21]$} & [1.29] & {$[1.25]$} & [1.21] \\
\hline Observations & 160 & 137 & 122 & 105 & 85 \\
\hline$R^{2}$ & 0.10 & 0.11 & 0.14 & 0.15 & 0.15 \\
\hline
\end{tabular}

Note: Dependent variable in the residual from the output growth regression in Table 6a. *,**,*** denote significance at 10,5 and 1 percent levels respectively. OLS estimation with robust standard errors. Change in output growth in trading partners is the change in the weighted average of output growth in trading partners between 2008-09 and 2005-07. 
Table 7a. Explaining Demand Growth During The Crisis

\begin{tabular}{|c|c|c|c|c|c|}
\hline $\begin{array}{c}\text { Sample } \rightarrow \\
\text { Explanatory Variables } \downarrow\end{array}$ & $\begin{array}{c}\text { (1) } \\
\text { All } \\
\text { countries }\end{array}$ & $\begin{array}{c}\text { (2) } \\
\text { Excl. oil } \\
\text { exporters }\end{array}$ & $\begin{array}{c}\text { (3) } \\
\text { Excl. low } \\
\text { income }\end{array}$ & $\begin{array}{c}\text { (4) } \\
\text { Excl. low } \\
\text { income and } \\
\text { fin. ctrs }\end{array}$ & $\begin{array}{c}\text { (5) } \\
\text { Excl. low } \\
\text { income, oil, } \\
\text { and fin. ctrs }\end{array}$ \\
\hline Trade openness & $\begin{array}{c}-0.28 \\
{[0.92]}\end{array}$ & $\begin{array}{l}-0.46 \\
{[0.94]}\end{array}$ & $\begin{array}{l}-0.34 \\
{[1.08]}\end{array}$ & $\begin{array}{c}0.85 \\
{[1.84]}\end{array}$ & $\begin{array}{l}-0.13 \\
{[1.93]}\end{array}$ \\
\hline Share of manufacturing in GDP & $\begin{array}{c}-14.95^{* *} \\
{[6.42]}\end{array}$ & $\begin{array}{l}-9.17 \\
{[6.43]}\end{array}$ & $\begin{array}{c}-17.72^{* *} \\
{[7.38]}\end{array}$ & $\begin{array}{c}-19.00^{* *} \\
{[8.19]}\end{array}$ & $\begin{array}{l}-10.85 \\
{[8.58]}\end{array}$ \\
\hline oil & $\begin{array}{c}0.17 \\
{[1.36]}\end{array}$ & & $\begin{array}{l}-0.43 \\
{[1.85]}\end{array}$ & $\begin{array}{c}-0.61 \\
{[1.88]}\end{array}$ & \\
\hline CA/GDP, 2007 & $\begin{array}{c}17.49^{* * *} \\
{[4.70]}\end{array}$ & $\begin{array}{c}17.52^{* * *} \\
{[5.66]}\end{array}$ & $\begin{array}{c}18.66^{* * *} \\
{[6.03]}\end{array}$ & $\begin{array}{c}18.48^{* * *} \\
{[6.40]}\end{array}$ & $\begin{array}{c}17.46^{* *} \\
{[6.87]}\end{array}$ \\
\hline Change in private credit to GDP, 2004-07 & $\begin{array}{c}-7.46 * * * \\
{[1.97]}\end{array}$ & $\begin{array}{c}-6.47^{* * *} \\
{[1.80]}\end{array}$ & $\begin{array}{c}-7.57^{* * *} \\
{[2.21]}\end{array}$ & $\begin{array}{l}-9.39 * \\
{[5.06]}\end{array}$ & $\begin{array}{l}-5.35 \\
{[4.61]}\end{array}$ \\
\hline log GDP per capita & $\begin{array}{c}-1.24^{* * *} \\
{[0.34]}\end{array}$ & $\begin{array}{c}-1.40^{* * *} \\
{[0.36]}\end{array}$ & $\begin{array}{l}-1.14^{*} \\
{[0.62]}\end{array}$ & $\begin{array}{c}-0.96 \\
{[0.75]}\end{array}$ & $\begin{array}{c}-1.91^{* *} \\
{[0.83]}\end{array}$ \\
\hline Trend demand growth & $\begin{array}{c}0.27 \\
{[0.28]}\end{array}$ & $\begin{array}{c}0.26 \\
{[0.26]}\end{array}$ & $\begin{array}{c}0.17 \\
{[0.33]}\end{array}$ & $\begin{array}{c}0.17 \\
{[0.36]}\end{array}$ & $\begin{array}{c}0.21 \\
{[0.29]}\end{array}$ \\
\hline Demand growth 2005-07 & $\begin{array}{c}0.02 \\
{[0.16]}\end{array}$ & $\begin{array}{c}-0.1 \\
{[0.18]}\end{array}$ & $\begin{array}{l}-0.00 \\
{[0.21]}\end{array}$ & $\begin{array}{l}-0.00 \\
{[0.23]}\end{array}$ & $\begin{array}{l}-0.35 * \\
{[0.19]}\end{array}$ \\
\hline Log financial openness & $\begin{array}{c}-0.13 \\
{[0.79]}\end{array}$ & $\begin{array}{c}-0.03 \\
{[0.79]}\end{array}$ & $\begin{array}{l}-0.18 \\
{[1.01]}\end{array}$ & $\begin{array}{l}-0.66 \\
{[1.63]}\end{array}$ & $\begin{array}{l}-0.14 \\
{[1.96]}\end{array}$ \\
\hline De facto peg & $\begin{array}{c}-0.32 \\
{[0.84]}\end{array}$ & $\begin{array}{c}-0.29 \\
{[0.78]}\end{array}$ & $\begin{array}{l}-0.35 \\
{[1.00]}\end{array}$ & $\begin{array}{c}-0.3 \\
{[1.16]}\end{array}$ & $\begin{array}{c}-0.5 \\
{[1.27]}\end{array}$ \\
\hline De facto intermediate e.r. regime & $\begin{array}{c}0.07 \\
{[0.81]}\end{array}$ & $\begin{array}{c}0.43 \\
{[0.84]}\end{array}$ & $\begin{array}{c}0.56 \\
{[0.98]}\end{array}$ & $\begin{array}{c}0.4 \\
{[1.07]}\end{array}$ & $\begin{array}{c}0.54 \\
{[1.06]}\end{array}$ \\
\hline Constant & $\begin{array}{c}15.10^{* * *} \\
{[3.57]}\end{array}$ & $\begin{array}{c}15.68^{* * *} \\
{[3.73]}\end{array}$ & $\begin{array}{c}15.55^{* * *} \\
{[5.63]}\end{array}$ & $\begin{array}{c}15.62^{* *} \\
{[6.90]}\end{array}$ & $\begin{array}{c}22.61^{* * *} \\
{[6.63]}\end{array}$ \\
\hline $\begin{array}{l}\text { Observations } \\
R^{2}\end{array}$ & 142 & 122 & 106 & 91 & 74 \\
\hline
\end{tabular}

Note to Table 6a: Dependent variable in the top panel is average growth in domestic demand over 2008-2009, times 100. ***,*** denote significance at 10,5 and 1 percent levels respectively. OLS estimation with robust standard errors. Trade openness is the sum of exports and imports divided by GDP. The manufacturing share is the ratio of manufacturing output to GDP. CA/GDP is the ratio of the 2007 current account balance to GDP. Change in private credit to GDP is the change in the ratio to GDP of private credit by banks and other financial institutions between 2004 and 2007. GDP per capita is measured in current U.S. dollars in 2007. LT demand growth is the average growth rate of total domestic demand over the period 1990-2007 (1995-2007 for some CEE and CIS countries), times 100. Demand growth 2005-07 is average growth in total domestic demand between 2005-2007, times 100. Financial openness is the sum of external financial assets and liabilities assets divided by GDP. De facto peg (intermediate e.r. regime) is a dummy variable taking the value 1 if the country had a de facto pegged (intermediate) exchange rate regime. 
Table 7b. Demand Growth Residuals and Change in Output Growth in Trading Partners

\begin{tabular}{|c|c|c|c|c|c|}
\hline $\begin{array}{c}\text { Sample } \rightarrow \\
\text { Explanatory Variables } \downarrow\end{array}$ & $\begin{array}{l}\text { All } \\
\text { countries }\end{array}$ & $\begin{array}{l}\text { Excl. oil } \\
\text { exporters }\end{array}$ & $\begin{array}{l}\text { Excl. low } \\
\text { income }\end{array}$ & $\begin{array}{l}\text { Excl. low } \\
\text { income } \\
\text { and fin. } \\
\text { Ctrs }\end{array}$ & $\begin{array}{l}\text { Excl. low } \\
\text { income, } \\
\text { oil, and } \\
\text { fin. Ctrs }\end{array}$ \\
\hline \multicolumn{6}{|c|}{ Dependent variable: residual from demand growth regression (Table 7a) } \\
\hline \multirow[t]{2}{*}{ Change in output growth in trading partners } & $1.08^{*}$ & $1.06 *$ & $1.18^{*}$ & $1.23 *$ & $1.10^{*}$ \\
\hline & {$[0.60]$} & {$[0.58]$} & [0.67] & {$[0.67]$} & [0.64] \\
\hline \multirow[t]{2}{*}{ Constant } & $4.45^{*}$ & $4.39 *$ & $5.04 *$ & $5.30 *$ & $4.79 *$ \\
\hline & {$[2.43]$} & {$[2.35]$} & [2.82] & {$[2.83]$} & {$[2.66]$} \\
\hline Observations & 140 & 120 & 104 & 89 & 72 \\
\hline$R^{2}$ & 0.07 & 0.09 & 0.08 & 0.09 & 0.11 \\
\hline
\end{tabular}

Note: Dependent variable in the residual from the output growth regression in Table $6 a . * * *$, *** denote significance at 10, 5 and 1 percent levels respectively. OLS estimation with robust standard errors. Change in output growth in trading partners is the change in the weighted average of output growth in trading partners between 2008-09 and 2005-07. 
Table 8. Consumption Growth (2008-2009)

\begin{tabular}{|c|c|c|c|c|c|}
\hline & (1) & (2) & (3) & (4) & (5) \\
\hline $\begin{array}{c}\text { Sample } \rightarrow \\
\text { Explanatory Variables } \downarrow\end{array}$ & $\begin{array}{l}\text { All } \\
\text { countries }\end{array}$ & $\begin{array}{l}\text { Excl. oil } \\
\text { exporters }\end{array}$ & $\begin{array}{l}\text { Excl. low } \\
\text { income }\end{array}$ & $\begin{array}{l}\text { Excl. low } \\
\text { income and } \\
\text { fin. ctrs }\end{array}$ & $\begin{array}{l}\text { Excl. low } \\
\text { income, oil, } \\
\text { and fin. ctrs }\end{array}$ \\
\hline GDP growth 2008-2009 & $\begin{array}{c}1.01 * * * \\
{[0.15]}\end{array}$ & $\begin{array}{c}1.01 * * * \\
{[0.16]}\end{array}$ & $\begin{array}{c}1.01 * * * \\
{[0.20]}\end{array}$ & $\begin{array}{c}1.27^{* * *} \\
{[0.26]}\end{array}$ & $\begin{array}{c}1.22 * * * \\
{[0.31]}\end{array}$ \\
\hline Financial openness dummy & $\begin{array}{c}0.88 \\
{[1.05]}\end{array}$ & $\begin{array}{c}2.57^{* *} \\
{[1.17]}\end{array}$ & $\begin{array}{c}0.21 \\
{[1.13]}\end{array}$ & $\begin{array}{c}0.08 \\
{[1.16]}\end{array}$ & $\begin{array}{c}1.72 \\
{[1.33]}\end{array}$ \\
\hline $\begin{array}{l}\text { Fin. openness dummy* GDP growth } \\
2008-09\end{array}$ & -0.14 & -0.33 & -0.12 & -0.02 & -0.24 \\
\hline & [0.39] & {$[0.30]$} & {$[0.41]$} & {$[0.23]$} & {$[0.40]$} \\
\hline Oil dummy & $\begin{array}{l}3.46 * \\
{[1.89]}\end{array}$ & & $\begin{array}{c}2.57 \\
{[2.31]}\end{array}$ & $\begin{array}{c}1.63 \\
{[2.10]}\end{array}$ & \\
\hline Current account / GDP, 2007 & $\begin{array}{l}-4.92 \\
{[9.95]}\end{array}$ & $\begin{array}{l}-14.63 \\
{[13.28]}\end{array}$ & $\begin{array}{c}-2.91 \\
{[12.40]}\end{array}$ & $\begin{array}{c}7.51 \\
{[9.76]}\end{array}$ & $\begin{array}{c}-3.94 \\
{[15.49]}\end{array}$ \\
\hline Change in private credit to GDP, 2004-07 & $\begin{array}{l}-2.42 \\
{[3.99]}\end{array}$ & $\begin{array}{l}-3.15 \\
{[3.45]}\end{array}$ & $\begin{array}{l}-2.68 \\
{[4.03]}\end{array}$ & $\begin{array}{c}13.3 \\
{[10.33]}\end{array}$ & $\begin{array}{l}9.85 \\
{[8.89]}\end{array}$ \\
\hline Constant & $\begin{array}{c}0.37 \\
{[0.85]}\end{array}$ & $\begin{array}{l}-0.37 \\
{[0.98]}\end{array}$ & $\begin{array}{c}1.09 \\
{[0.88]}\end{array}$ & $\begin{array}{l}-0.33 \\
{[1.28]}\end{array}$ & $\begin{array}{l}-0.82 \\
{[1.50]}\end{array}$ \\
\hline Observations & 145 & 125 & 108 & 93 & 76 \\
\hline$R^{2}$ & 0.36 & 0.37 & 0.36 & 0.46 & 0.40 \\
\hline
\end{tabular}

Note: Dependent variable is the average growth in private consumption over 2008-2009. $* * *, * * *$ denote significance at 10, 5 and 1 percent levels respectively. OLS estimation with robust standard errors. GDP growth 08-09 is the average growth rate of real GDP over 2008-09. The financial integration dummy takes the value of 1 if the sum of external assets and liabilities is at least 150 percent of GDP and the net external position is not worse than 50 percent of GDP. CA/GDP is the ratio of the 2007 current account balance to GDP. Private credit growth is the change in the ratio to GDP of private credit by banks and other financial institutions between 2003 and 2007. All ratios and growth rates are multiplied by 100 . 
Table 9. Total Domestic Demand Growth (2008-09)

\begin{tabular}{|c|c|c|c|c|c|}
\hline & (1) & (2) & (3) & (4) & (5) \\
\hline $\begin{array}{c}\text { Sample } \rightarrow \\
\text { Explanatory Variables } \downarrow\end{array}$ & $\begin{array}{l}\text { All } \\
\text { countries }\end{array}$ & $\begin{array}{l}\text { Excl. oil } \\
\text { export. }\end{array}$ & $\begin{array}{l}\text { Excl. low } \\
\text { income }\end{array}$ & $\begin{array}{l}\text { Excl. low } \\
\text { income } \\
\text { and fin. } \\
\text { ctrs }\end{array}$ & $\begin{array}{l}\text { Excl. low } \\
\text { income, } \\
\text { oil, and } \\
\text { fin. ctrs }\end{array}$ \\
\hline GDP growth 2008-2009 & $\begin{array}{c}1.14^{* * *} \\
{[0.10]}\end{array}$ & $\begin{array}{c}1.16 * * * \\
{[0.10]}\end{array}$ & $\begin{array}{c}1.17^{* * *} \\
{[0.12]}\end{array}$ & $\begin{array}{c}1.25^{* * *} \\
{[0.14]}\end{array}$ & $\begin{array}{c}1.22 * * * \\
{[0.15]}\end{array}$ \\
\hline Financial openness dummy & $\begin{array}{c}-0.34 \\
{[0.67]}\end{array}$ & $\begin{array}{c}0.41 \\
{[0.69]}\end{array}$ & $\begin{array}{c}-0.39 \\
{[0.73]}\end{array}$ & $\begin{array}{c}-0.67 \\
{[0.80]}\end{array}$ & $\begin{array}{c}0.19 \\
{[0.85]}\end{array}$ \\
\hline Financial open. dummy* GDP growth 2008-09 & $\begin{array}{c}-0.16 \\
{[0.16]}\end{array}$ & $\begin{array}{c}-0.33^{* *} \\
{[0.16]}\end{array}$ & $\begin{array}{c}-0.14 \\
{[0.16]}\end{array}$ & $\begin{array}{c}-0.12 \\
{[0.16]}\end{array}$ & $\begin{array}{l}-0.29 \\
{[0.22]}\end{array}$ \\
\hline Oil dummy & $\begin{array}{c}0.65 \\
{[1.38]}\end{array}$ & & $\begin{array}{l}-0.61 \\
{[1.37]}\end{array}$ & $\begin{array}{l}-0.95 \\
{[1.43]}\end{array}$ & \\
\hline Current account / GDP, 2007 & $\begin{array}{c}8.08^{* *} \\
{[4.04]}\end{array}$ & $\begin{array}{l}5.79 \\
{[5.02]}\end{array}$ & $\begin{array}{c}12.04 * * \\
{[4.73]}\end{array}$ & $\begin{array}{c}15.16 * * * \\
{[5.33]}\end{array}$ & $\begin{array}{l}10.51 \\
{[8.00]}\end{array}$ \\
\hline Change in private credit to GDP, $2004-07$ & $\begin{array}{c}-5.04 * * * \\
{[1.62]}\end{array}$ & $\begin{array}{c}-5.25 * * * \\
{[1.46]}\end{array}$ & $\begin{array}{l}-3.79 * \\
{[2.05]}\end{array}$ & $\begin{array}{c}2.39 \\
{[3.80]}\end{array}$ & $\begin{array}{c}0.23 \\
{[3.89]}\end{array}$ \\
\hline Constant & $\begin{array}{c}0.28 \\
{[0.52]}\end{array}$ & $\begin{array}{l}-0.03 \\
{[0.58]}\end{array}$ & $\begin{array}{c}0.2 \\
{[0.56]}\end{array}$ & $\begin{array}{l}-0.25 \\
{[0.69]}\end{array}$ & $\begin{array}{c}-0.44 \\
{[0.78]}\end{array}$ \\
\hline Observations & 146 & 126 & 109 & 94 & 77 \\
\hline $\mathrm{R}^{2}$ & 0.73 & 0.78 & 0.75 & 0.74 & 0.76 \\
\hline
\end{tabular}

Note: Dependent variable is the average growth in total domestic demand over 2008-2009. ***, *** denote significance at 10, 5 and 1 percent levels respectively. OLS estimation with robust standard errors. GDP growth 200809 is the average growth rate of real GDP over 2008-09. Financial openness is the sum of external financial assets and liabilities assets divided by GDP. CA/GDP is the ratio of the 2007 current account balance to GDP. Private credit growth is the change in the ratio to GDP of private credit by banks and other financial institutions between 2003 and 2007. All ratios and growth rates are multiplied by 100 . 
Figure 1. Change in GDP Growth and GDP per apita

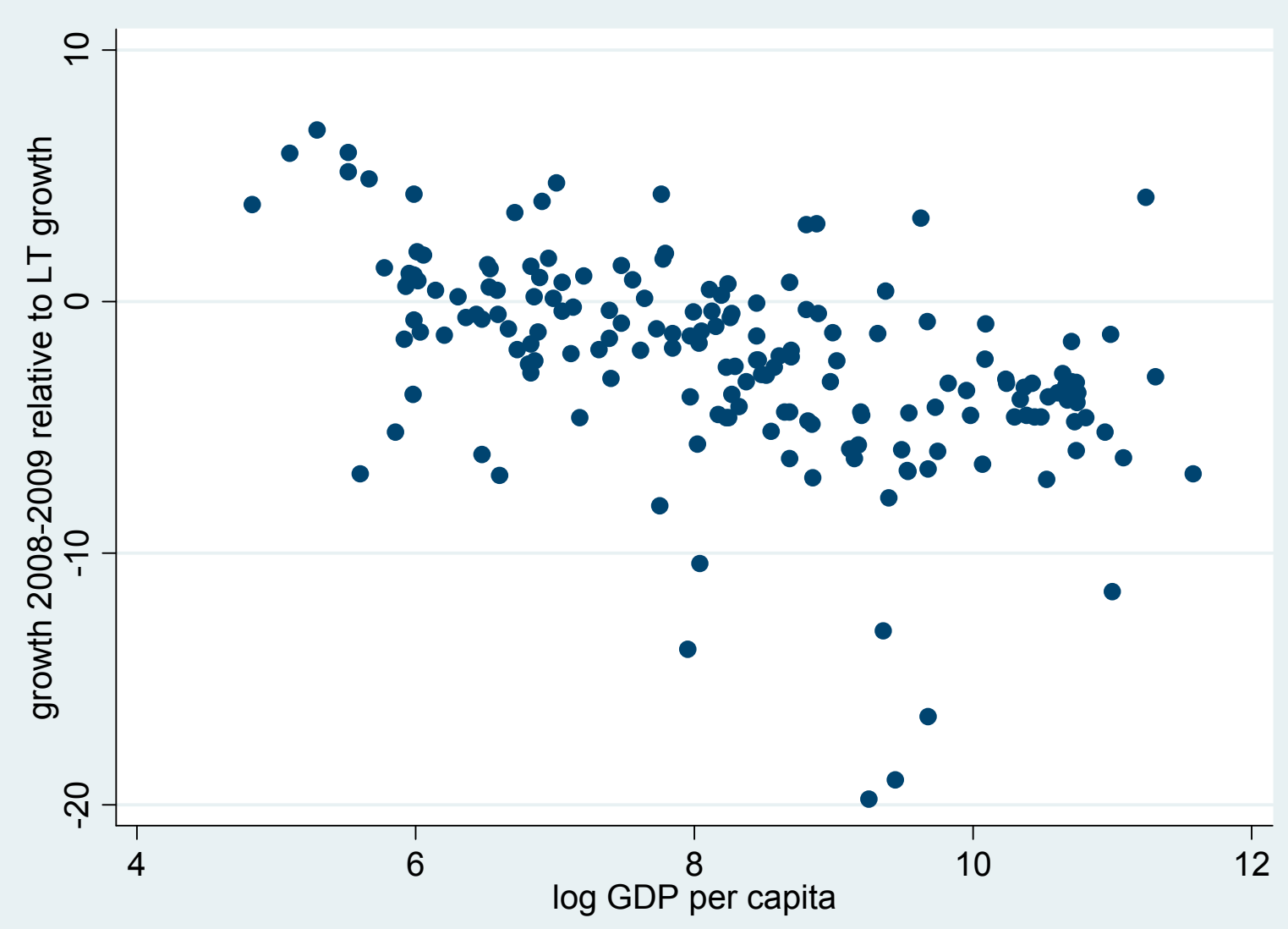

Note: Horizontal axis: log nominal GDP per capita in US dollars (2007). Vertical axis: change in GDP growth between 2008-2009 and 1990-2007. Whole sample. The correlation coefficient equals -0.48. 
Figure 2. Change in Demand Growth and Current Account Balance

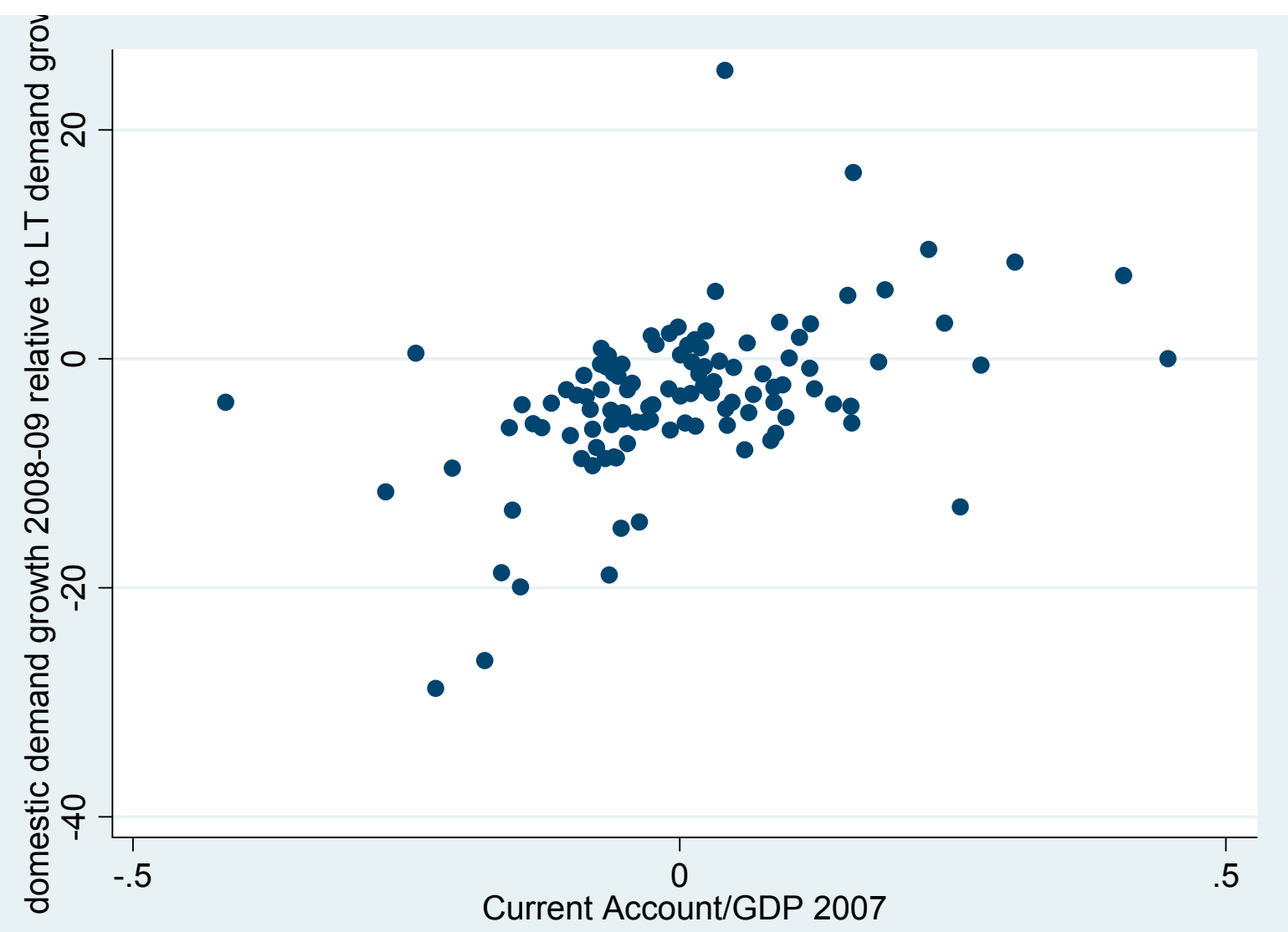

Note: Horizontal axis: 2007 current account balance in percent of GDP. Vertical axis: change in total domestic demand growth between 2008-2009 and 1990-2007. Sample excludes low-income countries. Correlation coefficient equals 0.47 . 
Figure 3. Decline in demand growth and growth in private credit

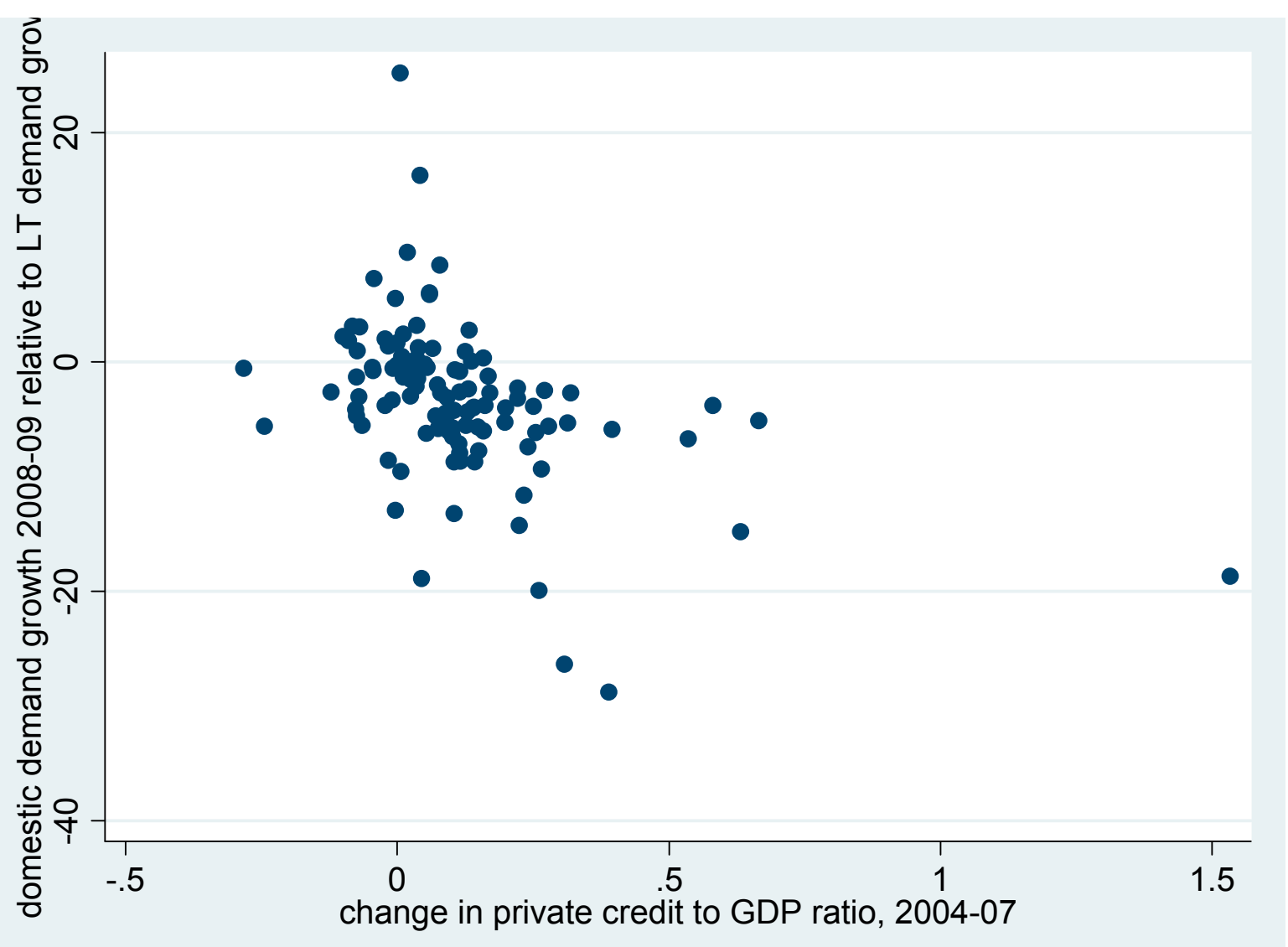

Note: Horizontal axis: change in the ratio of private credit to GDP, 2004-2007. Vertical axis: change in total domestic demand growth between 2008-2009 and 1990-2007. Sample excludes low-income countries. Correlation coefficient equals -0.44 ( -0.40 excluding Iceland, the right-most point in the graph). 